\title{
Trapped at Sea. Using the Legal and Regulatory Framework to Prevent and Combat the Trafficking of Seafarers and Fishers.
}

\author{
Rebecca Surtees ${ }^{1}$
}

DOI: $10.21827 / 5 \mathrm{a} 86 \mathrm{a} 7 \mathrm{a} 0 \mathrm{dd} 73 \mathrm{c}$

\author{
Keywords \\ HUMAN TRAFFICKING, SEAFARERS, FISHERS, INTERNATIONAL LAW, 3PS (PREVENTION, \\ PROTECTION, PROSECUTION), LEGAL AND REGULATORY FRAMEWORK.
}

\begin{abstract}
The breadth and diversity of trafficking for forced labour has become increasingly recognised over the past several years, including heightened attention to human trafficking within the seafaring and commercial fishing industries. Not only are these sectors where trafficking abuse can and does take place, but there are also aspects of these sectors that may lend themselves particularly to human trafficking abuses due to the nature of this form of trafficking as well as the legal and regulatory framework in place. The article begins by framing what constitutes trafficking at sea, both in the commercial fishing sector and in the merchant fleet and then presents the legal and regulatory framework to combat trafficking at sea - namely, international anti-trafficking law, international maritime law and the international law of the sea. The article then considers the "three P paradigm" of anti-trafficking (that is, prevention, protection and prosecution) and how improved policies, regulation and legislation (and, as importantly, enforcement) in these areas have the potential to contribute to an improved situation for seafarers and fishers-to both prevent and combat trafficking in commercial fishing and the merchant fleet, while also noting differences between the two sectors. The analysis also draws on the perspective and experiences of men trafficked in the seafaring and commercial fishing sectors to firmly situate the discussion in the practical realm and articulate what, in concrete terms, can be done to effectively prevent and combat trafficking of seafarers and fishers.
\end{abstract}

Rebecca Surtees is an anthropologist and senior researcher at NEXUS Institute, a human rights policy and research centre in Washington DC. She has conducted research on various aspects of human trafficking in SE Asia, SE Europe, the former Soviet Union and West Africa. Her research has covered different aspects of the trafficking issue; recent studies include: After trafficking. (Re)integration in the Mekong (2013); Trafficked at sea. Exploitation of Ukrainian seafarers (2012); Coming home. Challenges in family reintegration (2012); Out of sight? Challenges in identifying trafficked persons (2012); Measuring success of anti-trafficking interventions in the criminal justice sector. Who decides and how? (2012); Trafficked men, unwilling victims (2008); and Leaving the past behind. When trafficking victims decline assistance (2007). 


\section{Introduction ${ }^{2}$}

The breadth and diversity of trafficking for forced labour has become increasingly recognised over the past several years - amongst researchers, practitioners and policymakers as well as within national and international justice systems. This has included increased attention on trafficking and exploitation within the seafaring and commercial fishing industries. Not only are these sectors where trafficking abuse can and does take place, but there are also aspects of these sectors that may lend themselves particularly to human trafficking abuses due to the nature of this form of trafficking (i.e. isolation at sea, limited contact with authorities on land and at sea) as well as the legal and regulatory framework in place (including lopsided regulation and lack of enforcement). There are three key areas where improved policies, regulation and legislation (and, as importantly, enforcement) have the potential to contribute to an improved situation for seafarers and fishers - to both prevent and redress human trafficking within these labour sectors. These can generally be framed around what is known as the "three $\mathrm{P}$ paradigm" of prevention, protection and prosecution to guide action and interventions in combating human trafficking. ${ }^{3}$

After framing, in Part II, what constitutes trafficking at sea, Part III presents the legal and regulatory framework to combat trafficking at sea (namely, international anti-trafficking law, international maritime law and the international law of the sea). The article then considers, in subsequent sections, each of the "three Ps" with attention to how gaps and issues in the legal and regulatory frameworks of the

2 This article was drafted in the framework of the IOM and NEXUS Institute Human Trafficking Research Series.

Thanks are due particularly to my colleague Laura S. Johnson (Research Associate, NEXUS Institute) who was very involved in the drafting of this article, in particular in researching and disentangling the complexities of the international legal and regulatory framework related to trafficking at sea. She was also a great sounding board for ideas throughout the drafting process and kindly reviewed various versions of this draft. I am also grateful to Anne Gallagher (Independent legal scholar) and Lisa Rende Taylor (Independent researcher/scholar), and Gunnar Stølsvik (Head of project, Norwegian National Advisory Group against Organised IUU-fishing, Norwegian Ministry of Fisheries and Coastal Affairs, Norway), each of who kindly reviewed the paper and provided helpful feedback and suggestions. The paper was also reviewed by colleagues at IOM; thanks to Amanda Gould (Research and Data and Analysis Specialist, IOM Geneva), Nathalie Siegrist (CT database assistant) and Jonathan Wolfish (Intern, IOM). Finally, I am grateful to Christina Parello (Legal Analyst and Project Coordinator, NEXUS Institute) and Stephen Warnath (Founder and CEO, NEXUS Institute) for their review of the article and constructive inputs. This publication was made possible through support provided by the United States Department of State, under the terms of Grant No. S-SGTIP-09-GR-0070. The opinions expressed herein are those of the author and do not necessarily reflect the views of the United States Department of State.

3 The '3P paradigm'--referring to "prevention" of the act of trafficking, "protection" of victims of trafficking, and "prosecution" of perpetrators of trafficking--is a framework used by governments around the world to combat human trafficking. The paradigm was pioneered by the United States government in 1998 in accordance with efforts to combat violence against women and trafficking in women and girls. Samarasinghe, V., "Confronting Globalization in Anti-trafficking Strategies in Asia", Brown Journal of World Affairs vol. 10, ed. 1, 2003, 91-104.In 2009, United States Secretary of State Hillary Rodham Clinton announced the addition of a 'fourth P' to the paradigm-"partnership"--which will serve as a pathway to progress in the efforts against trafficking. United States Department of State, "The '3P' Paradigm: Prevention, Protection, and Prosecution", Democracy and Global Affairs, 14 June 2010, available online at <www.state.gov/documents/organization/144603.pdf> (accessed 6 October 2013). The 3P paradigm is outlined in the United States' Trafficking Victims Protection Act (TVPA) and in the United Nations Protocol to Prevent, Suppress and Punish Trafficking in Persons, Especially Women and Children, supplementing the United Nations Convention Against Transnational Organised Crime of 15 November 2000, 2237 UNTS 319, subsequently referred to as the Trafficking Protocol. 
seafaring and commercial fishing sectors provide space for trafficking exploitation and also limit options for remedy. The article also explores how improved and tailored legislation, policies and regulations-centred around these three Ps-have the potential to both prevent and combat trafficking in commercial fishing and the merchant fleet, while also noting differences between the two sectors. The analysis also draws on the perspective and experiences of men trafficked in the seafaring and commercial fishing sectors to firmly situate the discussion in the practical realm and articulate what, in concrete terms, can be done to effectively prevent and combat trafficking of seafarers and fishers.

\section{Trafficking at Sea. Framing the Discussion}

There are various forms of labour for which people are trafficked, including within the seafaring sector (or merchant fleet) and the commercial fishing sector. The United Nations Protocol to Prevent, Suppress and Punish Trafficking in Persons, the primary source of international anti-trafficking law, defines trafficking in human beings in article $3 \mathrm{a}$ as:

[...] recruitment, transportation, transfer, harbouring or receipt of persons, by means of the threat or use of force or other forms of coercion, of abduction, of fraud, of deception, of the abuse of power or of a position of vulnerability or of the giving or receiving of payments or benefits to achieve the consent of a person having control over another person, for the purpose of exploitation. Exploitation shall include, at a minimum, the exploitation of the prostitution of others or other forms of sexual exploitation, forced labour or services, slavery or practices similar to slavery, servitude or the removal of organs. ${ }^{4}$

"Trafficking at sea", in the context of this discussion, involves seafarers and fishers undertaking at-sea activities (including fishing, transportation and fish processing while on vessels, rafts, fishing platforms or otherwise offshore). It does not include other examples of trafficking in the fishing sector, ${ }^{5}$ nor does it include shore-based

4 Art. 3(a) Trafficking Protocol. Article 3 further specifies that 'The recruitment, transportation, transfer, harbouring or receipt of a child for the purpose of exploitation shall be considered 'trafficking in persons' even if this does not involve any of the means set forth in subparagraph (a)' and defines a child as any persons under eighteen years of age. Idem Art. 3(c)-(d).

5 See, for example, FAO and ILO, Afenyadu, D., Child Labour in Fisheries and Aquaculture, A Ghanaian Perspective, FAO Workshop on Child Labour in Fisheries and Aquaculture in Cooperation with ILO FAO Headquarters, 2010, available online at ilo.org/fileadmin/user_upload/fao_ilo/pdf/WorkshopFisheries2010/WFPapers/DAfenyaduChild _LabourGhana.pdf> (accessed 6 October 2013); ECLT, Donda, S. and Njaya, F., Review of Child Labour Potential in the Malawi's Fisheries Sector, Paper for the National Conference in Eliminating Child Labour in Agriculture in Malawi, 2012, available online at <eclt.org/site/wpcontent/uploads/2012/10/Child-labour-in-Fisheries-in-Malawi-FINAL.pdf> (accessed 6 October 2013); Golo, H., Poverty and Child Trafficking in Ghana: A Study of the Fishing Sector, Institute of Social Studies, 2005, available online at <thesis.eur.nl/pub/9703/> (accessed 6 October 2013); Johansen, R., "Child trafficking in Ghana", UNODC Perspectives, vol. 1, 2006, 4-7; and FAO and ILO, Westlund, L., Guidance on addressing child labour in fisheries and aquaculture, 2013, available online at $<$ fao.org/docrep/018/i3318e/i3318e.pdf> (accessed 6 October 2013). 
operations (e.g. fish/seafood processing and packaging, port-based work and shorebased fish harvesting). ${ }^{6}$

A fisher, according to Article 1(e) of the ILO Work in Fishing Convention, is:

\begin{abstract}
a person employed or engaged in any capacity or carrying out an occupation on board any fishing vessel, including persons working on board who are paid on the basis of a share of the catch but excluding pilots, naval personnel, other persons in the permanent service of a government, shore-based persons carrying out work aboard a fishing vessel and fisheries observers. ${ }^{7}$
\end{abstract}

Thus, in lay terms, a fisher is any individual who is a member of the crew on board a fishing vessel. ${ }^{8}$ When someone is involved in some aspect of fishing-e.g. getting fish out of the sea, processing and handling fish, transporting and storing in the refrigerator, navigating or operating the fishing vessel- $\mathrm{s} /$ he is a fisher.

A seafarer differs from a fisher according to Article II(f) of the Maritime Labour Convention, which defines a seafarer as: 'any person who is employed or engaged in any capacity on board a ship to which this Convention applies'. ${ }^{9}$ The MLC applies to all ships, whether publicly or privately owned, ordinarily engaged in commercial activities, other than ships engaged in fishing. ${ }^{10}$ Seafarers hold a variety of professions and ranks on board commercial ships and each role ${ }^{11}$ carries unique responsibilities that are essential to the successful operation of the vessel. ${ }^{12}$ Despite differences, there is an overlap between seafarers and fishers, particularly in relation to fish carriers. For example, in a recent study of trafficked seafarers from Ukraine, a number of men were

6 Trafficking into land based seafood processing factories, while not explored here, has been documented in Southeast Asia and elsewhere. See, for example, On Point, Ashbrook, T., Exploited Labor in the USA, 10 July 2012, available online at <onpoint.wbur.org/2012/07/10/forced-labor-inthe-usa> (accessed 6 October 2013); Solidarity Center, Brennan, M., Out of sight, out of mind. Human trafficking and exploitation of migrant fishing boat workers in Thailand, 2009, available online at <solidaritycenter.org/files/thailand_Out_of_Sight_Eng.pdf> (accessed 6 October 2013); International Organization for Migration; Robertson, P., Trafficking of fishermen in Thailand, 2011, available online <iom.int/jahia/webdav/shared/shared/mainsite/activities/countries/docs/thailand/Traffickingof-Fishermen-Thailand.pdf> (accessed 6 October 2013); Solidarity Center, REPORT: The Degradation of Work: The True Cost of Shrimp, 2008, available online at <solidaritycenter.org/files/pubs_True_Cost_of_Shrimp.pdf> (accessed 6 October 2013); Surtees, R., After trafficking. Experiences and challenges in the (re)integration of trafficked persons in the GMS, UNIAP and NEXUS, 2013, available online at $<$ nexusinstitute.net/publications/pdfs/After\%20trafficking_Experiences $\% 20$ and $\% 20$ challenges $\% 20 \mathrm{i}$ n\%20\%28Re\%29integration\%20in\%20the\%20GMS.pdf >; and Verite, REPORT: Research on Indicators of Forced Labour in the Supply Chain of Shrimp in Bangladesh, 2012, available online at $<$ verite.org/sites/default/files/images/DOL-BANGLADESH-FINAL- ADA COMPLIANT.pdf> (accessed 6 October 2013).

7 Work in Fishing Convention (WIF Convention), 14 June 2007, ILO Convention 188.

8 According to the WIF Convention a fishing vessel is 'any ship or boat, of any nature whatsoever, irrespective of the form of ownership, used or intended to be used for the purpose of commercial fishing.' Art. 1(g) WIF Convention.

9 Maritime Labour Convention (MLC), 7 February 2006, ILO Convention.

10 Art. 2 MLC.

11 The wide variety of roles seafarers hold include being responsible for navigation; supervising crew; cargo operations; maintaining the vessel including maintaining and repairing deck equipment and engineering equipment; maintaining stores and accommodations; and even preparing and serving meals.

12 The MLC excludes fishing vessels, inland navigation, naval ships and ships below 200 gross tonnage in coastal areas from the scope of the convention. Art. 2 MLC. 
trafficked to Russia to work aboard illegal crabbing vessels. ${ }^{13}$ While professional seafarers, they carried out their occupation on fishing vessels and many were also forced to engage in fishing. As such, they fall under the definition of fishers according to the WIF Convention. Because international law provides seafarers and fishers different protections and because the conditions of work are different between the merchant fleet and the commercial fishing sector, this discussion distinguishes between seafarers and fishers according to the type of vessel (fishing or commercial) on which they work.

Trafficking has generally been documented within the fishing industry and, arguably, most commonly as part of illegal, unreported and unregulated (IUU) fishing operations. ${ }^{14}$ IUU fishing vessels are those that operate without or in contravention of appropriate fishing licenses, in marine protected areas or without reporting their catch in accordance with applicable fishing regulations. ${ }^{15}$ IUU fishing vessels may remain at sea for extended periods of time, avoid contact with authorities and are often substandard (i.e. of poor quality or even dangerous due to their age, design, construction or equipment). Crew on IUU fishing vessels often either do not have contracts or have entered into contracts with complicit recruitment agencies that cannot be pursued when labour or human rights violations occur or when a crew or vessel is arrested. As a consequence of its clandestine nature, IUU fishing exposes fishers to a range of risks and violations, including the possibility of human trafficking. ${ }^{16}$ Fishers on IUU fishing vessels often suffer physical and/or psychological mistreatment, inhumane living and working conditions and, in some cases, crew members have been locked in their quarters or even placed in chains. Crew members who are considered 'inefficient' or who 'cause problems' on board IUU fishing vessels are sometimes abandoned in foreign ports. ${ }^{17}$ Trafficked fishers on IUU fishing vessels

13 Surtees, R., Trafficking in men, a trend less considered. The case of Ukraine and Belarus, International Organization for Migration, Migration Research Series 36, 2008. The overlap is evident here as the men used their training as seafarers to work operating the crabbing vessels, but they also worked as fishers directly responsible for the crab catch. That being said, as all of their work took place on board a fishing vessel, for the purposes of this discussion they must be considered fishers.

14 The complete definition of IUU fishing can be found in Art. 3.1-3.3, Food and Agriculture Organization of the United Nations, International Plan of Action to Prevent, Deter and Eliminate Illegal, Unreported and Unregulated Fishing, 2001, available online at $<$ fao.org/docrep/003/y1224e/y1224e00.HTM> (accessed 12 October 2013), subsequently referred to as IPOA-IUU. Some organisations and experts also refer to IUU fishing as 'fisheries crime' or 'marine living resource crime'.

15 Some forms of IUU fishing are also transnational organised environmental crime. See, e.g., Norwegian National Advisory Group Against Organized IUU-Fishing, Stolsvik, G., Cases and materials on illegal fishing and organized crime, 2009, available online at <regjeringen.no/upload/FKD/Vedlegg/Diverse/2010/FFA/CasesAndMaterials_FFApubl.pdf> (accessed 12 October 2013).

16 Environmental Justice Foundation (EJF), REPORT: All at Sea: The Abuse of Human Rights Aboard Illegal Fishing Vessels, available online at <ejfoundation.org/oceans/all-at-sea-report> (accessed 12 October 2013).

17 Australian Govt. Dept. of Agriculture Fisheries \& Forestry \& ITF, Gianni, M. and Simpson, W., The Changing Nature of High Seas Fishing - How Flags of Convenience Provide Cover for Illegal, Unreported and Unregulated Fishing, 2005, 33-34, available online at <daff.gov.au/fisheries/iuu/high-seas> (accessed 12 October 2013). See also UNODC, De Coning, E., Transnational organised crime in the fishing industry. Focus on trafficking in persons, smuggling in migrants and illicit drugs trafficking, 2011, available online at <unodc.org/documents/human-trafficking/Issue_Paper__TOC_in_the_Fishing_Industry.pdf $>$ (accessed 12 October 2013); International Transport Worker's Federation, REPORT: Out of sight, out of mind: Seafarers, Fishers \& Human Rights (ITF Report), 2006, available online at < itfseafarers.org/files/extranet/-1/2259/HumanRights.pdf> (accessed 12 
are forced to commit fisheries crimes (i.e. to engage in illegal fishing), which can potentially influence how they are perceived and received by authorities-i.e. as perpetrators of fishery crimes rather than as victims of human trafficking.

While trafficking at sea is often associated with IUU fishing, it also occurs within regulated fishing sectors. One study of sixty-three Filipino fishers trafficked through Singapore onto long haul fishing vessels describes how the men were isolated at sea, with vessels only docking once a year unless repairs were needed. Even when vessels were berthed in Singapore, the captain withheld the men's passports to prevent them from entering the port. The men were deceived about the conditions and nature of the work and were subjected to threats and intimidation, substandard living and working conditions, surveillance and arbitrary punishment, inadequate provision of medical treatments and the non-payment of salary. ${ }^{18}$ Similarly, a study of foreign charter vessels (FCVs) ${ }^{19}$ in New Zealand's Exclusive Economic Zone (EEZ) found that serious physical, mental, sexual and contract abuse was commonplace, with many crews forced to work in substandard and often inhumane conditions. Foreign crew also did not receive the legal minimum wage entitlements outlined under the New Zealand Code of Practice (CoP). ${ }^{20}$ In some (perhaps very many) instances, the exploitation of fishers rose to the level of human trafficking because they were prohibited from leaving the vessel, were deceived about work and payment, had wages withheld and were forced to work by the threat or use of force or other forms of coercion. ${ }^{21}$

October 2013) ; and Whitlow, J., The Social Dimension of IUU Fishing, 2004, available online at $<$ hoecd.org/dataoecd/32/32/31492524.PDF> (accessed 12 October 2013).

18 Yea, S., Troubled Waters: Trafficking of Filipino Men into the Long Haul Fishing, 2012, available online at $<$ twc2.org.sg/wp-content/uploads/2013/01/Troubled_waters_sallie_yea.pdf> (accessed 12 October 2013).

19 Foreign charter vessels (FVCs) are foreign vessels, complete with foreign crew, that in this case are chartered by New Zealand companies to fish in New Zealand's Exclusive Economic Zone (the sea zone between 12 and 200 nautical miles from New Zealand's coast in which New Zealand has exclusive rights to the use of marine resources). Interdisciplinary Project on Human Trafficking, Gallagher, A., "Exploitation in the Global Fishing Industry: New Zealand Researchers and Advocates Secure a Rare and Important Victory", 4 May 2013, available online at $<$ traffickingroundtable.org> (accessed 12 October 2013).

20 New Zealand Asia Institute: University of Auckland, Stringer, C., Simmons, G. and Coulston, D., Not in New Zealand's waters surely? Labour and human rights abuses aboard foreign fishing vessels, 2011, 13, available online at <humanrights.auckland.ac.nz/webdav/site/humanrights/shared/Research/Notin-NZ-waters-surely-NZAI.pdf $>$ (accessed 12 October 2013). As a result of this study, internal activism, external pressure and its own investigation into FVCs, New Zealand's Government recently announced that, after 2016, all commercial fishing vessels operating in New Zealand waters will need to be registered as New Zealand ships and carry the New Zealand flag. In other words, beginning in 2016, FVCs will no longer be allowed to fish in New Zealand's EEZ. Gallagher, A., supra nt. 19. A recent threat to this 'success', however, came in August 2013 when New Zealand's Primary Production Select Committee allowed a loophole in the new rules governing foreign charter vessels, which will permit some foreign vessels to continue to fish in New Zealand waters. Harre, T., Press Release of 1 August 2013 for Slave Free Seas, available online at <slavefreeseas.org/workspace/downloads/slave-free-seas-press-release-1-august-2013.pdf> (accessed 12 October 2013).

21 The difference between exploitative or bad labour conditions and human trafficking is important to distinguish as it is only when a situation becomes trafficking that the related legal frameworks can be applied to protect and assist trafficking victims. In the fishing sector in particular, where labour conditions are notoriously difficult, trafficked fishers may not even realise that they are victims. See, e.g., International Organization for Migration, Surtees, R., Trafficked at Sea. The exploitation of Ukrainian seafarers and fishers, 2012, 117-118, available online at <publications.iom.int/bookstore/free/Trafficked_at_sea_web.pdf> (accessed 12 October 2013). In some cases, while the labour conditions on board a vessel may be atrocious and there may be labour 

seafarers and fishers.

Trafficking has also been documented amongst seafarers in the merchant fleet. ${ }^{22}$ Ukrainian men trafficked to Turkey as seafarers were tasked with transporting cargo to ports along the Mediterranean coastline. They occupied different positions on the vessel: as captain, senior assistant, cook, electrician and regular rank and file seafarers. Not only were work conditions harsh and dangerous, but living conditions were also very difficult with inadequate food and water and no electricity for light or warmth. Their documents were withheld and they were regularly threatened by the vessel owner. ${ }^{23}$ Similarly, numerous reports of Filipino seafarers point to labour abuses on ships, including situations of slave-like conditions in the cruise-ship industry and on board commercial cargo ships. ${ }^{24}$

By definition, trafficked seafarers and fishers are exposed to a wide range of abuses and violations that constitute trafficking exploitation. ${ }^{25}$ Trafficked seafarers and fishers in different situations, in different regions, have described the lack of basic necessities and inhumane conditions:

Food that was delivered for ten days was stretched out for a month. Food was extremely scarce... There was almost no drinking water. We had to collect rainwater or melt snow (Ukrainian seafarer/fisher trafficked on a Russia crabbing vessel). ${ }^{26}$

Workers aboard many vessels were required to bathe in salt water, causing rashes. They would often find that the water heater was switched off before their shift had ended. Drinking water for crew was a rusty colour and unboiled, while the officers enjoyed boiled or bottled water. A number of interviewees from different vessels complained of food being inadequate in quality or past its use by date. On one vessel after about twenty days into a forty day voyage, food supplies were rationed and the galley locked. Often crews were fed just fish and rice or indeed in the case of one entire crew they were fed rotten fish bait (Foreign fishers aboard Korean foreign charter vessels in New Zealand's EEZ). ${ }^{27}$

Seafarers and fishers are forced to work long hours, sometimes days on end, with only a few minutes of break in this time. They generally work for little or no pay;

or human rights issues at stake, if fishers are not being exploited by the threat or use of force or other forms of coercion then the situation cannot be characterised as trafficking.

22 Idem, 37.

23 Idem, 69-81.

24 Verité, REPORT: Hidden Costs in the Global Economy: Human Trafficking of Philippine Males in Maritime, Construction and Agriculture, Verité Grant \# S-GTIP-07-GR-007, 2009, 11-12, available online

<verite.org/sites/default/files/images/Verit\%C3\%A9\%20TIP\%20Report\%20Male\%20Trafficking. pdf $>$ (accessed 13 October 2012).

25 Cf. Brennan, M., supra nt. 6; International Labour Office, International Labour Organization, De Coning, E., Caught at Sea: Force Labour and Trafficking in Fisheries, 2013, available online at $<$ ilo.org/wcmsp5/groups/public/---ed_norm/---

declaration/documents/publication/wcms_214472.pdf> (accessed 13 October 2013); EJF, supra nt. 16; Robertson, P., supra nt. 6; Stringer, C., et al., supra nt. 20; Surtees, R., supra nt. 21; Surtees, R., supra nt. 6; and Yea, S., supra nt. 18.

26 Surtees, R., supra nt. 21, 73.

27 Stringer, C., et al., supra nt. 19, 9. 
wages are commonly withheld ${ }^{28}$ One Thai boy, trafficked aboard a fishing boat in Indonesian waters, worked from early morning until late at night, placing nets and pulling them from the sea, sorting and packing fish and moving them to the freezer storage. He was permitted only a short time to rest and eat. When the supervisor was 'unsatisfied', he was physically and verbally abused. He could not escape because the boat was far out at sea for months at a time. He received only a tiny fraction of his promised in wages. ${ }^{29}$ Similarly, Ukrainian seafarers and fishers suffered brutal working conditions, leading to serious injuries, illness and even death:

When we were on the Russian crabbing boat, we slept only two hours a day and all the time we were working. Sometimes people got really hurt when they were standing next to the crab traps. Sailors were standing and literally almost sleeping. The traps were falling and sometimes people lost their hands or legs. Nobody cared about this there (Ukrainian seafarer/fisher trafficked on a Russia crabbing vessel) ${ }^{30}$

Violence and assault is, for many trafficked fishers and seafarers, commonplace. One man from Myanmar trafficked onto a fishing boat in Thailand described extreme violence perpetrated against fellow workers resulting in serious injury and death:

I saw that the owner did not like the workers to take time off even when they were not feeling well. They whistled to start working and, if some did not appear, they would pour boiling water on them. Some died from the injuries. They also threw ice at them, beat them with tools. One Thai man died from the beatings he suffered. I also saw one [foreign-looking] man who was beaten up and lost his teeth because he could not work well as he did not understand the language and instructions. I also saw some people die from accidents [on board]. If someone fell into the water, they would not bother rescuing. ${ }^{31}$

Another Myanmar man trafficked in Thailand for fishing suffered extreme violence while trafficked. He was threatened with a gun and told that he would be shot if he tried to escape. Two other workers were shot and killed in front of him when they tried to escape. The work was harsh and he was forced to work even when he was seriously ill. He was exploited for four and a half years. ${ }^{32}$ Ukrainian seafarers/fishers

28 Cf. Brennan, M., supra nt. 5; De Coning, E., supra nt. 24; EJF, supra nt. 16; Environmental Justice Foundation, REPORT: Sold to the Sea - Human Trafficking in Thailand's Fishing Industry, 2013, available online at < ejfoundation.org/sites/default/files/public/Sold_to_the_Sea_report_lo-resv2.pdf $>$ (accessed 13 October 2013); Robertson, P., supra nt. 5; Stringer, C., et al., supra nt. 19; Surtees, R., supra nt. 21; Surtees, R., supra nt. 6; and Yea, S., supra nt. 18.

29 Surtees, R., supra nt. 6, 216. See also Verite, REPORT: Research on Indicators of Forced Labor in the Supply Chain of Fish in Indonesia: Platform (Jermal) Fishing, Small-Boat Anchovy Fishing, and Blast Fishing, 2012, available online $<$ digitalcommons.ilr.cornell.edu/cgi/viewcontent.cgi?article $=2779 \&$ context $=$ globaldocs $>$ (accessed 13 October 2013).

30 Surtees, R., supra nt. 21, 75.

31 Surtees, R., supra nt. 6, 119.

32 Surtees, R., supra nt. 6, 128. Similar reports of violence have surfaced in recent years. For example, in an analysis of forty-nine Cambodian men and boys trafficked onto Thai long-haul fishing boats, $59 \%$ of the victims reported having witnessed a murder by the boat captain. UNIAP, Exploitation of Cambodian Men at Sea: Facts About the Trafficking of Cambodian Men Onto Thai Fishing Boats, SIREN series CB-03, 2009, available online at <no-trafficking.org/reports_docs/siren/siren_cb3.pdf> (accessed 13 October 2013). 
trafficked to Russia also described extreme violence and abuse as a means of compelling them to work:

There was a sort of supervisor. He was overseeing people, making sure everybody was working. He was sometimes beating people. One [man] was bruised so badly, he was spitting blood... ${ }^{33}$

When I wrote a [request] to be sent home, the senior watchman beat me and kicked out my teeth. He threatened to cripple and cut me. There was the same treatment for every one of the sailors. ${ }^{34}$

While not all cases of harsh labour conditions and labour exploitation at sea constitute human trafficking, many do. Greater appreciation is needed of the full range of factors - e.g. deception, coercion, violence, exploitation and abuse-experienced by seafarers and fishers including when and how cases rise to the level of human trafficking. For example, many seafarers and fishers willingly enter into contracts with crewing/manning agencies but are deceived about the conditions and outcomes-e.g. in terms of the kind of work, the conditions of work, wages (if they get paid at all), the amount of debt to be repaid and so on-all of which can add up to labour trafficking. Addressing violence and violations in the seafaring and commercial fishing sectors requires an effective and appropriate legal and regulatory framework, which is transnational in scope and enforced across jurisdictions and legal regimes. Understanding the various legal and regulatory opportunities to prevent and combat trafficking at sea is an essential starting point for future discussion and intervention.

\section{The Legal and Regulatory Framework to Combat Trafficking at Sea}

Understanding and addressing human trafficking at sea involves disentangling a raft of legal and jurisdictional complexities. Trafficking at sea involves persons who have left home and are exploited at sea, outside their country of origin. ${ }^{35}$ Trafficked seafarers and fishers may find themselves aboard vessels that are un-flagged or flagged to another State ${ }^{36}$, exploited by nationals of their own or other nations, ashore in a foreign port or never entering port and/or suffering abuse and exploitation on the high seas or in waters that fall within the territory of one or various States. A further complication is that seafarers and fishers are often recruited through crewing agencies that may or may not have an official presence in their home countries.

International law that may be used to combat trafficking at sea falls generally into three areas: 1) international anti-trafficking law, including human rights law as it applies to trafficking-related exploitation; 2) international maritime law; and 3) the international law of the sea. While these three legal and regulatory frameworks overlap to varying degrees, understanding the laws that can be used to improve the situations of fishers and seafarers requires parsing the complex bodies of international

33 Surtees, R., supra nt. 21, 78.

34 Ibid.

35 In the trafficking context, a "destination country" refers to the location to which the victim is (or is intended) to be exploited. A "transit country" refers to any State through which a victim passes while being trafficked and an "origin country" is the source State from which a trafficking victim originated (usually the victim's country of origin).

36 At sea a ship must fly the flag of the country to which it is registered. Art. 91 UNCLOS, infra nt. 38. 
law relevant to trafficking at sea. For example, the law of the sea is not synonymous with maritime law. The law of the sea is the body of public international law that primarily draws on the United Nations Convention on the Law of the Sea (UNCLOS). ${ }^{37}$ In general, the law of the sea deals with relationships between States (e.g. issues such as national versus international waters) and defines the rights and responsibilities of nations in their use of the world's oceans. By contrast, international maritime law addresses relationships between private individuals or companies.

This section provides an overview of the three intersecting legal frameworks applicable to combating trafficking in this context. It also outlines the international laws and regulations currently in place that can potentially contribute to the prevention of trafficking at sea, the protection of trafficked fishers and seafarers and the prosecution of trafficking crimes that take place at sea. This includes attention to how gaps and issues in the legal and regulatory frameworks provide space for trafficking exploitation and limit options for remedy.

\section{III.1. International Anti-Trafficking Law}

The primary source of international anti-trafficking law is the United Nations Protocol to Prevent, Suppress and Punish Trafficking in Persons ${ }^{38}$ (hereafter referred to as the Trafficking Protocol). The Trafficking Protocol was adopted by the United Nations in 2000 and entered into force in 2003. Currently it has 155 States Parties. ${ }^{39}$ In addition to providing an agreed definition of trafficking in persons (see Part II), the Trafficking Protocol contains provisions (of varying normative strength) on preventative measures, assistance to and protection for victims and the criminalisation of trafficking crimes. The Trafficking Protocol stipulates that States Parties shall adopt or strengthen legislative or other measures to establish trafficking crimes as criminal offenses (Article 5) and establish comprehensive policies to prevent and combat trafficking (Article 9). The Trafficking Protocol also encourages (but does not require) States Parties, in Article 6, to implement measures to provide for the assistance and protection of trafficking victims. ${ }^{40}$

Another important source of international anti-trafficking law is the Council of Europe Convention on Action against Trafficking in Human Beings (CoE Convention), ${ }^{41}$

37 United Nations Convention on the Law of the Sea of 10 December 1982, U.N. Doc. A/CONF.62/122, 21 I.L.M. 1261, subsequently referred to as UNCLOS.

38 GA Resolution 39574 (55th) of 15 November 2000, Protocol to Prevent, Suppress and Punish Trafficking in Persons, Especially Women and Children, Supplementing the United Nations Convention Against Transnational Organized Crime, 2237 UNTS 319; Doc. A/55/383, available online at <treaties.un.org/Pages/ViewDetails.aspx?src=TREATY\&mtdsg_no=XVIII-12a\&chapter=18\&lang $=e n>$ (accessed 20 October 2013). The Trafficking Protocol is also known as the 'Palermo Protocol' or 'UN TIP Protocol'.

39 Ibid. As of June 2013 the Trafficking Protocol has been ratified by 155 States.

40 Assistance measures may be offered by governmental, non-governmental or international organisations and might include but are not limited to: accommodation/housing, medical care, psychological assistance, education, vocational training, life skills, employment and economic empowerment, legal assistance, transportation and family mediation/counselling. Surtees, R., "Re/integration of trafficked persons: how can our work be more effective?", KBF \& NEXUS Institute Issues paper \# 1, 2008, 48.

41 Council of Europe Convention on Action against Trafficking in Human Beings of 3 May 2005, CETS No. 197, subsequently referred to as CoE Convention. The Council of Europe is an international organisation which comprises 47 countries of Europe. The CoE Convention is only directly relevant for Council of Europe members. In spite of its limited application in the international setting, the $\mathrm{CoE}$ Convention is an important regional treaty with the potential to influence treaty-making processes beyond Europe. See, e.g., de Boer-Buquicchio, M., "The 
which is a comprehensive regional treaty primarily focused on the protection of trafficking victims and the safeguarding of their rights, although it also aims to prevent trafficking and prosecute traffickers. A noteworthy distinction from the Trafficking Protocol is that the CoE Convention obliges States Parties to assist and protect trafficking victims. The CoE Convention stipulates that States Parties shall protect the private life and identity of victims (Article 11), provide victims with a reflection period and residence permit in appropriate cases (Articles 13 and 14), provide trafficked persons with free legal assistance and the right to compensation (Article 15) and provide assistance to victims that includes, at a minimum, standards of living capable of ensuring their subsistence; access to emergency medical treatment; translation and interpretation services, when appropriate; counselling and information in a language that they can understand; assistance to enable their rights and interests to be presented and considered at appropriate stages of criminal proceedings against offenders; and access to education for children (Article 12). ${ }^{42}$ The CoE Convention also stipulates that States Parties shall adopt such legislative or other measures as may be necessary to appropriately identify trafficking victims (Article 10). ${ }^{43}$

While the Trafficking Protocol and the $\mathrm{CoE}$ Convention are legally binding instruments that provide an anti-trafficking framework for the international community, their effectiveness will ultimately depend on how their key obligations are incorporated into national law and practice. To encourage EU Member States to incorporate these key obligations and to develop legal norms and standards to prevent and punish trafficking (and protect and assist victims), the EU Council has issued directives and plans on trafficking and related issues, the most significant being the 'Directive of 5 April 2011 on preventing and combating trafficking in human beings and protecting its victims'. ${ }^{44}$ The 2011 EU Directive establishes minimum rules concerning the definition of criminal offences and sanctions in the area of trafficking in human beings and introduces common provisions, taking into account the genderspecific phenomenon of trafficking, to strengthen the prevention of trafficking and the protection of victims thereof. ${ }^{45}$ Non-treaty instruments such as the 2011 EU Directive

Effectiveness of Legal Frameworks and Anti-Trafficking Legislation", Speech given at the UNODC Panel Session, 15 February 2008, available online at $<$ coe.int/t/dg2/trafficking/campaign/Docs/News/DSGVienna2_en. asp> (accessed 20 June 2013).

42 The CoE Convention entered into force in 2008. As of June 2013 it has been ratified by 40 States. Infra Council of Europe Treaty Office, available online at $<\mathrm{http}: / /$ conventions.coe.int/ $>$ (accessed 20 June 2013).

43 Identification is the process by which a trafficked person is formally identified as trafficked (or potentially trafficked) in an appropriate, sensitive and timely fashion and referred for assistance at home and/or abroad, depending on the situation. Fafo Institute \& NEXUS Institute, Brunovskis, A. and Surtees, R., REPORT: Out of sight? Factors and challenges in the identification of trafficked persons, 17 April 2012, available online at <fafo.no/pub/rapp/20255/20255.pdf> (accessed 20 October 2013).

44 Directive 2011/36/EU of the European Parliament and of the Council of 5 April 2011 on preventing and combating trafficking in human beings and protecting its victims, and replacing Council Framework Decision 2002/629/JHA, OJ L101, 15 April 2011, 1-11, subsequently referred to as the EU Directive.

45 Art. 1 EU Directive. The EU Directive recognises the gender-specific phenomenon of trafficking and that women and men are often trafficked for different purposes and states that for this reason, 'assistance and support measures should also be gender-specific where appropriate'. Par. (3) EU Directive. Further, the EU Directive notes that 'push' and 'pull' factors in trafficking may be different depending on the sectors concerned. Ibid. These recognitions are of critical importance in combating trafficking at sea, as the fishing and seafaring sectors are unique lines of work where trafficking victims are most commonly men. 
play an important role in reiterating and expanding existing legal principles of international anti-trafficking law. ${ }^{46}$

Finally, trafficking is a human rights violation and, as such, international human rights law can be applied to trafficking-related exploitation and used to combat trafficking. International human rights treaties contain prohibitions on practices that are closely associated with trafficking, such as forced labour and child labour. ${ }^{47}$ Further, these treaties prohibit behaviours or practices that have been linked to trafficking, such as ethnic or racial discrimination, slavery, torture and inhumane treatment. ${ }^{48}$ International human rights law aids in anti-trafficking as human rights law guarantees basic rights to individuals and access to remedies for violations of those rights. For individuals trafficked at sea, the laws of the State able to exercise jurisdiction over the vessel will be critically important to the provision of assistance and protection to victims and to the prosecution of trafficking crimes. Therefore it is critical that States bring their national laws in accordance with the primary instruments of international anti-trafficking law, including human rights law as it applies to trafficking-related exploitation.

\section{III.2. International Maritime Law}

International maritime law (also referred to as admiralty law) is the body of laws, conventions and treaties that govern international private business or other matters involving ships and shipping. Its relevance for anti-trafficking efforts at sea comes from the key obligations in international maritime law that make vessels and life at sea safer. The regulation of private vessels provides indirect opportunities to combat trafficking at sea. Obligations of maritime law that seek to directly protect crews and ensure fair and humane working conditions at sea can be used to protect and assist trafficked seafarers and fishers.

The primary sources of international maritime law are the instruments that collectively comprise the international regulatory regime for quality shipping: the International Convention for the Safety of Life at Sea (SOLAS), the International Convention on Standards of Training, Certification and Watchkeeping for Seafarers (STCW), the International Convention for the Prevention of Pollution from Ships (MARPOL) and the Maritime Labour Convention (MLC). The International Maritime Organization (IMO), the specialised agency of the United Nations

46 Gallagher, A., Commentary to the Recommended Principles and Guidelines on Human Rights and Human Trafficking, Office of the United Nations High Commissioner for Human Rights, 2010, 26. For an indepth discussion of 'soft law' (non-binding) instruments that serve as sources of international antitrafficking law, see idem, 24-28.

47 Idem, 37-39. For example, the 1930 Convention Concerning Forced and Compulsory Labour (ILO Convention 29), the 1957 Convention Concerning the Abolition of Forced Labour (ILO Convention 105) and the 1999 Convention Concerning the Prohibition and Immediate Action for the Elimination of the Worst Forms of Child Labour (ILO Convention 182) all address forced labour and child labour.

48 dem, 21. See, e.g., the 1966 International Covenant on Civil and Political Rights; the 1979 Convention on the Elimination of all Forms of Discrimination against Women (which requires States Parties to take all appropriate measures, including legislation, to suppress all forms of trafficking in women); the 1984 Convention against Torture, and Other Cruel, Inhuman or Degrading Treatment or Punishment (Convention against Torture); and the 1989 Convention on the Rights of the Child (which specifically prohibits trafficking in children for any purpose as well as the sexual exploitation of children and forced or exploitative labour). For a complete list of the relevant human rights treaties important to the international legal framework around trafficking see idem, 2022. 
responsible for measures to improve the safety and security of international shipping and to prevent marine pollution from ships, is responsible for supporting States in the effective implementation of their obligations under SOLAS, STCW and MARPOL. The MLC is an International Labour Organization (ILO) convention; the ILO supports States Parties in complying with obligations under the MLC.

Importantly, maritime law offers different protections depending on the classification of a ship (i.e. whether a SOLAS vesse $1^{49}$ or non-SOLAS vessel ${ }^{50}$ ) and the individuals on board. That is, under maritime law, fishing vessels are less regulated than the merchant fleet and crew aboard fishing vessels are, arguably, more vulnerable to abuse and exploitation, including human trafficking. It is, therefore, important to distinguish between a fishing vessel (and fishers) and a merchant vessel (and seafarers) because each is regulated by a distinct and specific body of applicable international maritime law. These bodies of law and their relevance in tackling human trafficking will each be considered in turn.

\section{III.2.1. Maritime Law Related Specifically to Seafarers}

With regard to seafaring, SOLAS (1974), STCW (1978) and the MLC (2006) ${ }^{51}$ are the primary instruments of international maritime law that offer mechanisms and impose obligations on States that, in some cases, may help to prevent and combat human trafficking. ${ }^{52}$

The International Convention for the Safety of Life at Sea (SOLAS) is an international maritime safety treaty that, in its successive forms, is generally considered the most important international treaty concerning the safety of merchant ships. SOLAS entered into force in 1980 and requires flag States ${ }^{53}$ to ensure that their ships comply with minimum safety standards in construction, equipment and operation, mechanisms that could be used indirectly to prevent trafficking in the seafaring sector. For example, Chapter 1 states that the inspection and survey of ships to ensure SOLAS compliance shall be carried out by officers of the State whose flag

49 International Convention for the Safety of Life at Sea of 1 November 1974, 1184 UNTS 3 , subsequently referred to as SOLAS. All commercial vessels are categorised as either SOLAS or nonSOLAS. SOLAS-convention vessels ships are all commercial vessels that fit within the definition of a SOLAS ship, which is any ship to which the SOLAS regulations apply, namely: a passenger ship engaged on an international voyage or a non-passenger ship of 500 tons gross tonnage or more engaged on an international voyage. Chapter 1, Regs. 1-5 SOLAS.

50 Fishing vessels are not generally covered by the SOLAS convention due to differences in their design and operation Chapter 1, Reg. 2(i) SOLAS defines a fishing vessel as 'a vessel used for catching fish, whales, seals, walrus or other living resources of the sea' and Chapter 1, Regulation 3 exempts fishing vessels from SOLAS.

51 Another key instrument of maritime law is MARPOL, the main international convention covering prevention of pollution of the marine environment by ships from operational or accidental causes. MARPOL consists of regulations aimed at preventing and minimising pollution from ships and includes six technical Annexes, the final of which entered into force in 2005. See The International Convention for the Prevention of Pollution from Ships of 2 November 1973, 12 I.L.M. 1319, subsequently referred to as MARPOL. MARPOL might be relevant to the trafficking of individuals at sea if it inadvertently provided an opportunity to identify victims, such as when port officials board a ship to examine the certificates required under MARPOL and determine whether they are valid and appropriate. However, the language of MARPOL does not directly aim to make life at sea safer or to protect seafarers or fishers, therefore it is not discussed in depth.

52 ITF Report, supra nt. 17, 9.

53 Vessels must fly the flag of the country to which they are registered: the State under whose protection the ship sails and to whose laws it must adhere. This is known as flag State responsibility. Art. 91, UNCLOS. 
the ship is entitled to fly and the government concerned must fully guarantee the completeness and efficiency of the inspection and survey. ${ }^{54}$ These guaranteed inspections result in certificates that must be carried on board the ship. The same Chapter authorises port States to verify that these valid certificates are on board a ship and to prevent a ship from leaving port if the certificate does not exist or if the vessel conditions do not appear to match the certification. ${ }^{55}$ These opportunities under SOLAS for flag State and port State ship inspections may provide opportunities to identify trafficking if authorised inspectors know what to look for during inspections and are able (and willing) to extend inspections to include crew on-board. Inspections could also translate into opportunities for legal recourse when violations occur and increased inspection and monitoring of the merchant sector could potentially serve as a deterrent in exploiting and trafficking seafarers. However, in most situations, inspectors are chiefly concerned with the condition of the vessels and are not necessarily trained to identify trafficking. Moreover, inspectors interact mainly with senior crew and have limited opportunities for interacting with seafarers and fishers.

SOLAS also offers some indirect protection to trafficked seafarers on board a SOLAS-convention ship; ships that comply with SOLAS regulations may afford more opportunities for trafficked seafarers to seek out and receive assistance. For example, the SOLAS requirement that all vessels (including fishing vessels) have VHFtransponders on board (automatic identification system or AIS) means that law enforcement officials could potentially track vessel movement and detect unusual behaviour at sea (AIS radio signals can be picked up from shore and by satellite). Further, the requirement that each vessel's AIS transponder have a unique vessel identifier means the vessel's identity can be traced. AIS data is accessible on a number of websites, making it possible to track the position and movement of vessels and may, therefore, provide an opportunity to identify and assist trafficked seafarers by anticipating and intervening at their next port of call. ${ }^{56}$ Seafarers who have been "out of touch" (and, in some cases, possibly trafficked or at least in a difficult situation) might potentially be identified through such a mechanism. SOLAS-convention ships are also safer ships, as they must meet the extensive safety standards set forth in the

54 Chapter 1, Reg. 6 SOLAS.

55 Chapter 1, Reg. 19 SOLAS. Specifically: 'Such certificate shall be accepted unless there are clear grounds for believing that the condition of the ship or of its equipment does not correspond substantially with the particulars of that certificate. In that case, the officer carrying out the control shall take such steps as will ensure that the ship shall not sail until it can proceed to sea without danger to the passengers or the crew.'

56 Chapter 5, Reg. 19.2.4, SOLAS. Even though fishing vessels are included, the protections offered to fishers under this Chapter remain limited as flag States may exempt fishing vessels from the requirement. Further, 'persons on board [fishing] vessels have been known to disengage the transponder when they reach the fishing grounds or when they engage in criminal activities. The Torremolinos Protocol contains provisions on radio communication equipment in Chapter IX, but these are not yet in force.' De Coning, E., supra nt. 25, 35. The European Union has attempted to address this issue for fishers. Since Council Regulation (EC) No. 2371/2002 came into force, all large-scale fishing vessels flagged to EU Member States are prohibited from engaging in fishing unless they have a Vessel Monitoring System (VMS) installed. A satellite-based VMS enables authorities to monitor a vessel's location through the receipt of hourly electronic reports on a vessel's location, course, and speed. EJF, Pirate Fishing Exposed: The Fight Against Illegal Fishing in West Africa and the $E U, \quad 2012, \quad$ available online at <ejfoundation.org/sites/default/files/public/Pirate\%20Fishing\%20Exposed.pdf> $\quad$ (accessed 20 October 2013), 27. 
regulations in order to be certified, which may, in some situations, serve to prevent trafficking aboard such vessels. ${ }^{57}$

The International Convention on Standards of Training, Certification and Watch keeping for Seafarers prescribes minimum standards relating to training, certification and watch keeping on an international level for seafarers, which countries are obliged to meet or exceed. ${ }^{58}$ Aimed at improving crews' competence and increasing the security of ships, the STCW entered into force in 1984 and underwent major revisions in 1995 and 2010. STCW sets forth requirements for minimum training and hours of rest and the 2010 amendments increased the rest hour requirements; expanded the application of work hours and rest periods to more personnel; and required the recording of rest hours. ${ }^{59}$ Minimum rest hour requirements are likely to be enforceable by Port State Control Officers who are authorised to check that ships maintain accurate records demonstrating that individual seafarers have been provided with the requisite minimum rest. For example, currently seafarers must have at least ten hours rest in a 24 hour period. To help further reduce the possibility of fatigue, much of the flexibility that previously applied under STCW has now been removed. ${ }^{60}$ The 2010 amendments also provided improved measures to prevent fraudulent practices associated with certificates of competency and to strengthen the monitoring of STCW compliance. ${ }^{61}$ The enforcement of these STCW protections for seafarers provides opportunities to identify trafficking situations when checking that ships are in compliance with STCW requirements and directly protects seafarers by setting forth training and rest requirements for crew.

The Maritime Labour Convention (MLC) is considered the 'fourth pillar' of the international regulatory regime for quality shipping. ${ }^{62}$ Adopted in 2006, it entered into force on August 20, 2013. ${ }^{63}$ As an ILO convention, it differs from those of the IMO in that it focuses on the rights of individual fishers and seafarers. ${ }^{64}$ Also known as the 'Seafarers' Bill of Rights', the MLC consolidates and revises 36 ILO Conventions and one Protocol, aiming to establish a comprehensive international instrument to govern seafarers' working and living conditions and create conditions of fair competition for ship owners. ${ }^{65}$ The MLC establishes specific standards and detailed guidance on implementing these standards at the national level through its Articles, Regulations

57 Chapter 5 requires States Parties to ensure that all ships are sufficiently and efficiently manned in terms of safety of life at sea. Chapter 4 sets forth detailed regulations for radio communications from a ship. Chapter 1 requires a State to conduct investigations of any casualty occurring on any ship entitled to fly its flag and to share the findings with the IMO. These opportunities for communication with an investigation of a merchant vessel may serve to identify a trafficking situation and to protect and assist trafficked seafarers.

58 International Convention on Standards of Training, Certification and Watchkeeping for Seafarers of 7 July 1978 (STCW), as amended, 1361 UNTS 2.

59 United States Coast Guard, "Implementation of the 2010 Amendments to the International Convention on Standards of Training, Certification and Watchkeeping for Seafarers, 1978-Hours of Rest and Security-Related Training", Federal Register, 4 January 2012.

60 International Centre for Advancing the Legal Protection of Seafarers, "ICS reminds ship owners to comply with STCW from the New Year", 23 December 2011.

${ }^{61}$ The 2010 amendments go as far as to require measures to prevent drug or alcohol abuse among seafarers.

62 As an ILO Convention, the ILO is responsible for supporting States Parties to the MLC in properly implementing the provisions they have agreed to. See ILO, Maritime Labour Convention, available online at <ilo.org/global/standards/maritime-labour-convention/lang--en/index.htm> (accessed 20 June 2013).

63 Ibid.

64 ITF Report, supra nt. 17, 9.

65 ILO, supra nt. 62. 
and Code. Because of its focus on seafarers' rights, the MLC is arguably the strongest tool of international maritime law in combating trafficking in the seafaring sector. However, the scope of the MLC is limited to seafarers; fishers currently lack a comparable instrument.

Article III of the MLC requires States Parties to ensure that the provisions of their national law and regulations respect the fundamental rights to freedom of association and the effective recognition of the right to collective bargaining; the elimination of all forms of forced or compulsory labour; the effective abolition of child labour; and the elimination of discrimination in respect of employment and occupation. ${ }^{66}$ Article IV guarantees seafarers the right to a safe and secure workplace; fair terms of employment; decent working and living conditions on board ship; and health protection, medical care, welfare measures and other forms of social protection. ${ }^{67}$ Article V requires a State to ensure that a ship eligible to fly its flag carries a maritime labour certificate and a declaration of maritime labour compliance. Failure to do so potentially exposes a ship to Port State Control actions. Authority is given to States Parties other than the flag State to determine if the ship is in compliance when a ship to which the MLC applies is in a port. This is an opportunity for inspection focused on the well-being of seafarers and is, therefore, an opportunity to identify trafficking on ships engaged in commercial activities. ${ }^{68}$

Further, the MLC regulations establish fourteen areas subject to mandatory compliance for certification and the issuance of certificates. ${ }^{69}$ The MLC regulations aim to protect seafarers from the vulnerabilities that often accompany or can lead to human trafficking situations at sea. For example, Regulation 1.4 states that all 'seafarers shall have access to an efficient, adequate and accountable system for finding employment on board ship without charge to the seafarer.' Regulation 2.1 seeks to ensure that seafarers have a fair employment agreement. Regulation 2.2 states that all seafarers shall be paid for their work regularly and in full accordance with their employment agreements and sets wage standards. Regulation 2.3 regulates hours of work and rest and 2.4 ensures that seafarers have adequate leave. States that have ratified the MLC must comply with all of the provisions of the MLC (i.e. the Articles, Regulations and Standards). ${ }^{70}$

\section{III.2.2. Maritime Law Related Specifically to Fishers}

66 Art. III, MLC.

67 Art. IV, MLC.

68 Fishers are excluded from the MLC. Art. II, MLC.

69 The areas that must be inspected for compliance include: minimum age; medical certification; qualifications of seafarers; use of any licensed or certified or regulated private recruitment and placement services; seafarers' employment agreements; payment of wages; hours of work and rest; manning levels for the ship; accommodation; on-board recreation facilities; food and catering; onboard medical care; health and safety and accident prevention; and on-board complaint procedures. See Waldron, J. and O'Neill, P., "U.S. Implementation of the Maritime Labour Convention", Lexology, 14 May 2013, available online at <lexology.com/library/detail.aspx?g=f4b421e9-10084 feb-8619-205f667b833f $>$ (accessed 20 June 2013).

70 The MLC Code also has Guidelines, which must be taken into consideration by ratifying States. The MLC Articles contain general statements of obligations and rights and the specific details of such obligations and rights are set out in the Regulations and the Code. The difference between the Regulations and the Code is that the Regulations are normally worded in very general terms, with the details of implementation being set out in the Code (i.e. the Standards and the Guidelines). See ILO, Maritime Labour Convention 2006 Frequently Asked Questions, online revised ed., 2012, available online at $<$ ilo.org/wcmsp5/groups/public/---ed_norm/--normes/documents/publication/wcms_177371.pdf> (accessed 26 August 2013). 
With regard to the fishing sector, the Torremolinos Protocol (1993) and its successive forms (i.e. the Cape Town Agreement) as well as the accompanying International Convention on Standards of Training, Certification and Watchkeeping for Fishing Vessel Personnel (STCW-F) ${ }^{71}$ are the primary instruments of international maritime law that offer mechanisms that could potentially be used to combat the trafficking of fishers. ${ }^{72}$ Both are IMO Conventions that focus on the fishing industry. Also of importance is the ILO Work in Fishing Convention (WIF Convention).

The Torremolinos Protocol was adopted in 1993 to update, amend and absorb the original 1977 Torremolinos Convention, which addressed the design, construction, equipment and port State maintenance and inspection standards for fishing vessels. ${ }^{73}$ Because sub-standard ships pose serious risks to the marine environment and the lives and health of fishers working on them ${ }^{74}$, the Torremolinos Protocol aimed to improve technologies and working conditions on fishing vessels and ensure activities were carried out in a sustainable manner. ${ }^{75}$ However, it never entered into force and was amended and 'replaced' by the Cape Town Agreement of $2012 .{ }^{76}$ In ratifying the Cape Town Agreement, States agree to amendments to the provisions of the 1993 Torremolinos Protocol so that they can come into force as soon as possible. ${ }^{77}$ If and when the Cape Town Agreement enters into force, it will offer protections to fishers similar to the protections that SOLAS currently offers seafarers, at least in relation to vessels connected to States Parties. Through this agreement there may be increased opportunities for trafficked fishers on board to be identified and assisted. For example, if port States are authorised to inspect and ensure compliance of fishing vessels with the Cape Town Agreement, there will be potential opportunities to identify trafficking situations. However this requires that authorised inspectors know what to look for and/or how to assist trafficked fishers as well as pursue legal recourse when violations occur. That being said, increased inspection and monitoring of the fishing sector could potentially deter the exploitation and trafficking of fishers.

The STCW-F Convention mandates common standards for crew members on board fishing vessels. STCW-F entered into force in 2012 and is the first attempt to

71 International Convention on Standards of Training, Certification and Watchkeeping for Fishing Vessel Personnel of 7 July 1995, subsequently referred to as STCW-F.

72 SOLAS is directly relevant for seafarers but fishing vessels are exempt from most of its provisions. The STCW applies to seafarers, but not to fishers. The MLC does not apply to ships engaged in fishing or similar operations.

73 Torremolinos Protocol of 1993 relating to the Torremolinos International Convention for the Safety of Fishing Vessels, 1977 of 2 April 1993, subsequently referred to as Torremolinos Protocol.

74 International Commission on Shipping, REPORT: Ships, Slaves and Competition, 2000, 21.

75 The Torremolinos Protocol contained safety requirements for the construction and equipment of new, decked, seagoing fishing vessels of 24 metres in length and over, including those vessels also processing their catch. Existing vessels were covered only in respect of radio requirements. Chapters covered matters such as: construction, watertight integrity and equipment; machinery and electrical installations and unattended machinery spaces; fire protection, detection, extinction, and firefighting; protection of the crew; life-saving appliances; emergency procedures, musters and drills; radiotelegraphy and radiotelephony; and ship borne navigational equipment.

76 Cape Town Agreement of 2012 on the Implementation of the Provisions of the 1993 Protocol relating to the Torremolinos International Convention for the Safety of Fishing Vessels, 1977, of 29 October 2012, IMO Document SFV-P/CONF. 1/16, subsequently referred to as Cape Town Agreement.

77 The Cape Town Agreement will enter into force 12 months after the date on which not less than 22 States the aggregate number of whose fishing vessels of $24 \mathrm{~m}$ in length and over operating on the high seas is not less than 3,600 have expressed their consent to be bound by it. See IMO, International Conference on the Safety of Fishing Vessels, 12 October 2012, available online at $<$ www.imo.org/About/Events/fishingconf/Pages/default.aspx> (accessed 31 May 2013). 
provide a binding international framework to improve the training and certification of crew in the globalised fishing industry. It aims to reduce the high accident rate by improving safety standards for crew on vessels greater than $24 \mathrm{M}$ in length that are non-SOLAS vessels. Like the STCW (which applies to seafarers), the STCW-F aims to improve the competence of crew and to increase the security of ships. In requiring the enforcement of these protections for fishers by ratifying States, the STCW-F will provide identification opportunities when checking that ships are in compliance with the requirements of STCW-F and pursue legal recourse when violations occur. ${ }^{78}$ However, the STCW-F Convention does not deal with manning issues ${ }^{79}$ and significant gaps remain in international maritime law in terms of providing fishers with individual rights.

The Work in Fishing Convention (WIF Convention) was developed as a parallel instrument to the MLC to address precisely the current gaps in the protection of fishers. The WIF Convention, supplemented by a WIF Recommendation (No. 199), was adopted in 2007 to protect the rights and promote the working conditions of fishers, including establishing minimum requirements for work on board; conditions of service; accommodation and food; occupational safety and health protection; and medical care and social security. ${ }^{80}$ The WIF Convention applies to all fishers and commercial fishing vessels and revised ILO Conventions specifically concerning the fishing sector ${ }^{81}$ to bring them up to date and to reach a greater number of the world's fishers, particularly those working on board smaller vessels. However, the WIF Convention is not yet in force and, to date, has received only two ratifications. ${ }^{82}$

\section{III.3. The Law of the Sea}

78 Since neither the Torremolinos Protocol nor the STCW-F are applicable to fishing vessels under $24 \mathrm{~m}$ in length, and recognising that the great majority of fishing vessels are smaller than this, voluntary guidelines have been prepared by the Food and Agricultural Organization (FAO), IMO and ILO covering the design, construction and equipment of fishing boats between $12 \mathrm{~m}$ and $24 \mathrm{~m}$ in length. These guidelines aim to serve as a guide to those concerned with framing national laws and regulations. See IMO, Fishing Vessel Safety, available online at <http://www.imo.org/OurWork/Safety/Regulations/_FishingVessels/Pages/Default.aspx > (accessed 2 June 2013). These non-mandatory instruments include the FAO/ILO/IMO Document for Guidance on Fishermen's Training and Certification and the revised Code of Safety for Fishermen and Fishing Vessels, 2005, and the Voluntary Guidelines for the Design, Construction and Equipment of Small Fishing Vessels, 2005.

79 This was 'to make ratification and implementation easier for all concerned.' IMO, International Convention on Standards of Training, Certification and Watchkeeping for Fishing Vessel Personnel, available online at <www.imo.org/ourwork/humanelement/pages/stcw-f-convention.aspx> (accessed 31 May 2013).

80 Ibid.

81 Namely: the Minimum Age (Fishermen) Convention, 1959 (No. 112), the Medical Examination (Fishermen) Convention, 1959 (No. 113), the Fishermen's Articles of Agreement Convention, 1959 (No. 114), and the Accommodation of Crews (Fishermen) Convention, 1966 (No. 126).

82 As of May 2013 the WIF Convention had only been ratified by Argentina and Bosnia and Herzegovina. The WIF Convention will come into force twelve months after the date on which it receives the ratification of ten Members, eight of which must be coastal States. In May 2012, representatives of the social partners at the EU level in the sea fisheries sector signed an agreement on working conditions for workers on board fishing vessels, an important step toward implementing the WIF Convention at the EU level. The social partners intend to ask the European Commission to give the agreement legal force by means of a directive. European Commission, Press Release: Working conditions in fisheries key agreement signed by social partners, 21 May 2012, available online at < http://europa.eu/rapid/press-release_IP-12-493_en.htm?locale=en> (accessed 22 June 2013). 
The United Nations Convention on the Law of the Sea (UNCLOS) is largely a codification of customary international law dealing with navigation and other uses of the ocean and is almost universally recognised ${ }^{83}$ as establishing the regime of law and order in the world's oceans and seas. ${ }^{84}$ UNCLOS establishes the jurisdictional regime applicable to sea-based activities, ${ }^{85}$ which, in practice, is critical in determining who is responsible for the identification of and assistance to trafficked persons as well as any prosecutions of trafficking crimes at sea. The issue of jurisdiction is particularly relevant in the context of trafficking at sea given the increased likelihood of transjurisdiction, with merchant and fishing vessels moving easily and often between jurisdictions. Determining who has legal and regulatory responsibilities to address trafficking at sea not only depends on the nationality of the victim and of the trafficker(s), but also on where the vessel is (i.e. the ports and waters it may enter) and the country to which the vessel is registered. The law of the sea provides the legal framework to make this determination.

UNCLOS divides the world's waters into multiple zones that, for present purposes, can be placed into three main categories-1) the high seas; 2) coastal State territory; and 3) territory where a coastal State may exercise some jurisdiction. Arguably, the national law of the flag State is always going to have weight. However, in territorial waters and ports, the national law of a coastal State may come into play.

The first category under UNCLOS comprises waters under neither sovereignty nor jurisdiction of any State: the high seas. The high seas (sometimes referred to as international waters) are all parts of the sea that are not included in the territorial sea or in the internal waters of a State; in exclusive economic zones (EEZs: sea zones prescribed by UNCLOS in which a State has sole exploitation rights over all natural resources ${ }^{86}$ ); or in the archipelagic waters of an archipelagic State. ${ }^{87}$ On the high seas jurisdiction is reliant on the system of flag State control. UNCLOS confers jurisdiction over a vessel to the flag State; ships have the nationality of the State whose flag they are entitled to fly. ${ }^{88}$ UNCLOS applies to all vessels (e.g. both merchant and fishing) and gives a flag State the authority and responsibility to exercise its jurisdiction and control in administrative, technical and social matters over ships flying its flag. ${ }^{89}$ Flag States are required to take measures so that ships that fly their flags comply with the

83 UNCLOS entered into force in 1994 and, as of 2012, 164 countries and the European Union have joined in the Convention. While the United States has not ratified UNCLOS, it does recognise the treaty as a codification of customary international law and the U.S. Navy and U.S. Coast Guard operate under its guidelines even in the absence of ratification. See Bower, E., Advancing the National Interests of the United States: Ratification of the Law of the Sea, Center for Strategic \& International Studies, 25 May 2012, available online at <http://csis.org/publication/advancing-national-interestsunited-states-ratification-law-sea $>$ (accessed 31 May 2013).

84 Customary international law refers to international obligations arising from established State practice ('a general practice accepted as law') as opposed to obligations arising from formal written international treaties. Article 38(1) of the Statute of the International Court of Justice. However, there are sections of UNCLOS that are new (i.e. not a codification of existing customary rules) such as the section on deep seabed mining and provisions on environmental protection.

85 UNCLOS is, therefore, also a source of maritime law. See United Nations, The Law of the Sea: Obligations of States Parties under the United Nations Convention on the Law of the Sea and Complementary Instruments, 2004.

86 The EEZ stretches from the seaward edge of the State's territorial sea up to 200 nautical miles (370 kilometres; 230 land miles) from its coast. Art. 57 UNCLOS.

87 Art. 86 UNCLOS.

88 Art. 91 UNCLOS. Article 91 specifies: 'There must exist a genuine link between the State and the ship.'

89 Art. 94 UNCLOS. 
standards laid down in the IMO treaties that they have ratified. ${ }^{90}$ Monitoring the condition of vessels includes measures needed to ensure that vessels are appropriately surveyed as to condition, equipment and manning. ${ }^{91}$ Flag States also have an obligation to take any steps necessary to secure observance with generally accepted international regulations, procedures and practices. ${ }^{92}$ The flag State's obligations in international law, including those imposed by treaties the State has ratified, extend to vessels on its register. In terms of trafficking at sea, if a State has ratified the Trafficking Protocol, the CoE Convention, related human rights treaties or any IMO and ILO conventions that are relevant in addressing the trafficking of seafarers or fishers, the legal obligations of those instruments apply.

Flag States also have specific obligations for inspection, the enforcement of jurisdiction and administration of their registered vessels. Not only must flag States provide ships registered under their flag with appropriate certificates to demonstrate that the ship has been inspected and complies with international laws and standards, but flag States must also enforce penal jurisdiction when there are breaches of regulations that lead to incidents. In other words, the flag State is in control of criminal and disciplinary powers. The flag State determines the national law governing the ship and how and where an action can be enforced in relation to that ship. ${ }^{93}$ In practice, this means that even in territorial seas, foreign States will usually defer to the law of the flag State when dealing with a vessel. ${ }^{94}$ On the high seas, the national anti-trafficking laws of the flag State will be critically important in identification and the provision of assistance and protection to victims and to the prosecution of traffickers.

Implementation and enforcement of flag State responsibility is not as simple as it may appear. Vessel owners (i.e. any person or corporation possessing title to a vessel

90 Flag States will, therefore, necessarily be responsible for such issues as manning, labour conditions and crew training, construction, maintenance and seaworthiness of ships, prevention of collisions and so on.

91 Flag States issue vessel safety certificates indicating compliance with the main international conventions, which are key to the port State control inspection system. See Hare, J., "Flag, Coastal and Port State Control - Closing the Net on Unseaworthy Ships and their Unscrupulous Owners", Sea Changes, vol. 16, 1994.

92 Ibid., and Hare, J., "Port State Control: Strong Medicine to Cure a Sick Industry", Georgia Journal of International Comparative Law - Special Admiralty Issue, vol. 26, ed. 3, 1997. See also Art. 94 UNCLOS.

93 There are some exceptions, namely in relation to piracy or slavery. Article 101 of UNCLOS defines piracy and Article 105 sets forth that 'on the high seas, or in any other place outside the jurisdiction of any State, every State may seize a pirate ship or aircraft or a ship or aircraft taken by piracy and under the control of pirates and arrest the persons and seize the property on board. The courts of the State which carried out the seizure may decide upon the penalties to be imposed and may also determine the action to be taken with regard to the ships, aircraft or property, subject to the rights of third parties acting in good faith.' Arts. 100-105 UNCLOS. The legal framework in place for the international community collectively to combat piracy and prosecute pirates is useful in drawing parallels to combatting trafficking and prosecuting traffickers at sea. See, e.g., Surbun, V., "The developing jurisprudence to combat modern maritime piracy: a crime of the high seas?", The Comparative and International Law Journal of Southern Africa 43, 2010. In terms of trafficking, further research is also needed on the use of UNCLOS Article 99 which states: 'Every State shall take effective measures to prevent and punish the transport of slaves in ships authorised to fly its flag and to prevent the unlawful use of its flag for that purpose. Any slave taking refuge on board any ship, whatever its flag, shall ipso facto be free.' Art. 99 UNCLOS specifies the 'transport' of slaves, which has important differences from the exploitation of seafarers and fishers on board vessels.

94 Yang, H., Jurisdiction of the Coastal State over Foreign Merchant Ships in Internal Waters and the Territorial Sea, International Max Planck Research School for Maritime Affairs at the University of Hamburg, 2006, 97. 
and the proceeds of its services) need not be (and often are not) present on board the vessel, which limits accountability when problems occur, including human trafficking. Some vessel owners charter the vessel to an operator, although this differs by context and region. Some registered vessel owners are essentially shell companies in a tax haven, particularly when the vessel is registered in a State that is unable or unwilling to exercise its jurisdiction and duties over the ship. ${ }^{95}$ It is difficult for flag States to exercise jurisdiction over a company with no assets or personnel in their territory.

In reality, many vessels fly what are known as 'flags of convenience' (FoCs). This refers to the business practice of registering a merchant ship or fishing vessel in a sovereign State different from that of the ship owners to reduce operating costs or avoid certain regulations. ${ }^{96}$ FoCs are from States with an open register that usually are unable or unwilling to take seriously their flag State responsibilities either in terms of enforcing their existing national laws or in terms of implementing laws that comply with their responsibilities under IMO and ILO treaties. ${ }^{97}$ This, then, provides space for the perpetration of a raft of potential violations, including the exploitation of seafarers and fishers in ways that constitute human trafficking at sea. Lack of regulation further limits opportunities for identification of those already aboard vessels or for escape from trafficking. There are also going to be limits to opportunities for prosecuting those perpetrating trafficking crimes when FoC States do not take their responsibilities seriously.

Liberia, for example, is a commonly used FoC. The Liberian Registry is one of the largest and most active shipping registers, with approximately 4,000 ships registered to the Liberian flag in 2013. But, according to the 2013 Trafficking in Persons Report issued by the U.S. Department of State, the Government of Liberia does not fully comply with the minimum standards for the elimination of trafficking. ${ }^{98}$ The Liberian government only recently achieved its first trafficking conviction using its 2005 anti-

95 INTERPOL has recognized the lack of transparency of vessel ownership information through the use of secrecy jurisdictions coupled with registration in flags of convenience or statelessness as a key challenge in law enforcement at sea. INTERPOL, REPORT: Meeting on the formation of an INTERPOL ad hoc Fisheries Crime Working Group, 16-17 February 2012.

96 For example, for workers on board ships with United States vessel owners but registered to a FoC, FoCs 'severely limit recourse to US or other courts in disputes over wages or a workplace injury. A US court ruled in 2003 that claims related to a boiler explosion aboard NCL's Norway, which killed 8 workers and injured 20, had to be filed in the Philippines to comply with the employment contract that had been signed in the Philippines. Similarly, the employment contract of a worker on a Bahamian-registered ship states any dispute or claims 'shall be governed and adjudicated pursuant to the laws of the Bahamas, regardless of any other legal remedies that may be available.' Klein, R.A., Cruise Ship Squeeze: The New Pirates of the Seven Seas, New Society Publishers, Gabriola Island, 2005, 48.

97 The EJF notes that FoC States allow foreign vessels to fly their flag for 'a few hundred dollars' and then 'notoriously overlook illegal practices such as the evasion of taxes and fisheries management regulations.' EJF, supra nt. 17, 18.

98 United States Department of State, REPORT: Trafficking in Persons Report 2013, available online at $<$ state.gov/j/tip/rls/tiprpt/2013/> (accessed 28 October 2013). Liberia was placed on the Tier 2 Watch List for the third year in a row in 2013. According to the TIP Report, Tier 2 countries are those 'whose governments do not fully comply with the TVPA's minimum standards, but are making significant efforts to bring themselves into compliance with those standards' and countries fall on the Tier 2 Watch List if 'a) The absolute number of victims of severe forms of trafficking is very significant or is significantly increasing; $b$ ) There is a failure to provide evidence of increasing efforts to combat severe forms of trafficking in persons from the previous year; or c) The determination that a country is making significant efforts to bring itself into compliance with minimum standards was based on commitments by the country to take additional future steps over the next year.' Tier 3 comprises 'countries whose governments do not fully comply with the minimum standards and are not making significant efforts to do so.' 
trafficking law and, overall, has made only minimal efforts to protect trafficking victims. ${ }^{99}$ If a trafficking situation were to be identified on a ship flying Liberia's flag on the high seas, Liberia's anti-trafficking legislation would apply and the protection of trafficked seafarers or fishers on board would depend on the Government of Liberia's ability or willingness to enforce that legislation. It is concerning that the most common FoCs, like Liberia, are those of States that have not brought their national laws and anti-trafficking efforts in accordance with the requirements of the Trafficking Protocol and, where relevant, the CoE Convention. ${ }^{100}$

The practice of "flag hopping" further complicates issues of flag State responsibility as vessels can re-flag and change names several times in a season, moving from one FoC to another. ${ }^{101}$ This is a common practice among IUU vessels used to confuse authorities and avoid prosecution. Flag hopping can be done frequently and cheaply since applications for new flags can often be sent by fax or made online and processed within 24 hours. ${ }^{102}$ Finally, there is the associated issue of 'flags of non-compliance' (FoNCs), States that, while not having an open registry like FoC States, nonetheless fail to enforce flag State obligations, particularly on the high seas or in distant water fisheries. ${ }^{103}$

The second category under UNCLOS comprises waters that are coastal State territory and, therefore, under the jurisdiction of coastal States. These include internal waters (waters on the landward side of a baseline such as rivers, canals and small bays) and territorial waters (coastal waters up to twelve nautical miles or twenty two kilometres from the baseline of a coastal State, also called the territorial sea). Within territorial waters, the coastal State sets laws and regulates the use of any resources. Coastal States are prevented, under UNCLOS Article 24, from hampering the 'innocent passage' of foreign ships through the territorial sea. ${ }^{104}$ Passage is 'innocent' as long as it is continuous and expeditious ${ }^{105}$ and is not 'prejudicial to the peace, good order or security of the coastal State' and takes place in conformity with UNCLOS and other rules of international law. ${ }^{106}$ Passage will not be considered 'innocent' if the vessel engages in one or more activities outlined in Article 19 of UNCLOS, ${ }^{107}$ the two

99 Ibid.

100 The States considered to be FOCs by the ITF's Fair Practices Committee (see infra nt. 303) that were included in the 2013 TIP Report are all ranked Tier 2 or lower. Antigua and Barbuda - Tier 2; Bahamas - Tier 2; Barbados - Tier 2 Watch List; Belize - Tier 2; Bolivia - Tier 2; Burma - Tier 2 Watch List; Cambodia - Tier 2 Watch List; Comoros - Tier 2 Watch List; Cyprus - Tier 2; Equatorial Guinea - Tier 3; Georgia - Tier 2; Honduras - Tier 2 Watch List; Jamaica - Tier 2; Lebanon - Tier 2 Watch List; Liberia - Tier 2 Watch List; Malt - Tier 2; Marshall Islands - Tier 2 Watch List; Mauritius - Tier 2; Moldova - Tier 2; Mongolia - Tier 2; Panama - Tier 2; St Vincent Tier 2; Sri Lanka - Tier 2 Watch List; Tonga - Tier 2.

101 INTERPOL has recognized the lack of transparency of vessel identity including renaming and reflagging as another key challenge in law enforcement at sea. INTERPOL, supra nt. 95.

102 EJF, supra nt. 17, 20.

103 Ibid.

104 Art. 17 UNCLOS.

105 This may include stopping and anchoring if it is incidental to ordinary navigation or proves necessary by force majeure or distress or for the purpose of rendering assistance to persons, ships, or aircraft in danger or distress. Art. 18 UNCLOS.

106 Art. 19 UNCLOS.

107 Outlawed are: (a) any threat or use of force against the sovereignty, territorial integrity or political independence of the coastal State; (b) any exercise or practice with weapons of any kind; (c) any act aimed at collecting information to the prejudice of the defence or security of the coastal State; (d) any act of propaganda aimed at affecting the defence or security of the coastal State; (e) the launching, landing or taking on board of any aircraft; (f) the launching, landing or taking on board of any military device; (g) the loading or unloading of any commodity, currency or person contrary 
most relevant for trafficking at sea being 1) the loading or unloading of any commodity or person contrary to the customs, fiscal, immigration or sanitary laws and regulations of the coastal State; and 2) any fishing activities. ${ }^{108}$

In spite of the primacy of flag State responsibility, a coastal State is also important in combating trafficking at sea when ships are present in waters under a coastal State's jurisdiction. A coastal State can, under international law, take certain (albeit) limited steps to regulate the activities of foreign vessels in its waters to protect its interests. A court of a coastal State will generally hear cases resulting from accidents or disputes that occur in the State's territorial or internal waters or ports. ${ }^{109}$

UNCLOS addresses criminal jurisdiction on board a foreign ship in territorial waters in Article 27, stating that:

the criminal jurisdiction of the coastal State should not be exercised on board a foreign ship passing through the territorial sea to arrest any person or to conduct any investigation in connection with any crime committed on board the ship during its passage except in four cases: 1) if the consequences of the crime extend to the coastal State; 2) if the crime is of a kind to disturb the peace of the country or the good order of the territorial sea; 3 ) if the assistance of the local authorities has been requested by the master of the ship or by a diplomatic agent or consular officer of the flag State; or 4) if such measures are necessary for the suppression of illicit traffic in narcotic drugs or psychotropic substances. ${ }^{110}$

While trafficking at sea, arguably, could be considered a crime that both disturbs 'the good order of the territorial sea' and 'with consequences that extend to the coastal State', under UNCLOS a State other than the flag State still has to notify the flag State and facilitate contact between the flag State and the ship's crew before taking steps to address the crime. ${ }^{111}$

A coastal State could potentially exercise criminal jurisdiction on board a foreign ship if a trafficking situation was identified in the coastal State's territorial waters. In such a situation the coastal State's courts could hear the case and the coastal State's national laws would apply. While not a trafficking case, the McRuby Case is an

to the customs, fiscal, immigration or sanitary laws and regulations of the coastal State; (h) any act of wilful and serious pollution contrary to this Convention; (i) any fishing activities; (j) the carrying out of research or survey activities; (k) any act aimed at interfering with any systems of communication or any other facilities or installations of the coastal State; (1) any other activity not having a direct bearing on passage. Art. 19 UNCLOS.

108 Irrespective of whether passage is innocent or not, under UNCLOS Article 27(1) States retain the capacity to enforce their criminal law in respect of crimes committed on passing ships in a number of specified situations of which some have relevance for human trafficking - namely if the consequences of the crime extend to the coastal State; if the crime disturbs the peace of the country or the good order of the territorial sea; or if the master of the vessel or its flag State has requested the coastal State to assist. However, there are restrictions on the capacity of a coastal State to enforce national laws on vessels merely passing through the territorial sea. Gallagher, A. and David, F., The International Law of Migrant Smuggling, Cambridge University Press, Cambridge, forthcoming 2013.

109 Yang, H., supra nt. 94, 97.

110 Art. 27 UNCLOS.

111 For example, in France, port authorities are understood to be able intervene in three hypotheses: if the crime is committed by a non-crew member; if the intervention of local authorities was requested by the Master of the vessel or if the peace and good order of the port was compromised. Bardin, A., "Coastal State's Jurisdiction over Foreign Vessels", Pace International Law Review, vol. 14, 2002, 3031. 
example of a coastal State asserting criminal jurisdiction over a foreign vessel and demonstrates the complex jurisdictional issues owing to the multi-national nature of cases at sea. In the 1994 McRuby Case, ten stowaways (nine from Ghana and one from Cameroon) were found on board the McRuby vessel (owned by MC Shipping of New York, managed by V-Ships of Monaco, registered in the Bahamas, crewed by Ukrainians and off Portugal when the crime took place). The stowaways were discovered on the high seas and all but one were killed by the crew to avoid having to return them back to Ghana. The surviving stowaway (who escaped and hid on the vessel) contacted the police upon arrival in France and the French court ruled that it had jurisdiction because part of the crime had been committed in the territorial waters of France. ${ }^{112}$ It, therefore, seems that if a trafficked seafarer or fisher contacted the police in a coastal State to report a trafficking crime, the coastal State should be able to exercise jurisdiction and apply its national laws in protecting and assisting the victim(s) and prosecuting the trafficker(s).

That being said, the McRuby Case is unique and, in practice, flag State jurisdiction is generally favoured. Because of this and as a result of problems with FoCs and flag State implementation (such as FoNCs), States have signed Memorandum of Understanding (MoUs) to put into place a system of Port State Control (PSC), which extends a coastal State's jurisdiction to allow for the inspection of foreign ships in national ports to verify that the conditions, equipment, labour conditions and operation of the ship comply with the requirements of maritime law's international conventions. ${ }^{113}$ PSC seeks to ensure that as many ships as possible are inspected while, at the same time, preventing ships being delayed by unnecessary inspections. The primary responsibility for a ship's standards still rests with the flag State but PSC provides a 'safety net' to catch substandard ships. ${ }^{114}$ It is up to port States to exercise PSC in a manner consistent with their own domestic legislation, with due attention to international instruments and ILO and IMO resolutions. Many States have promulgated domestic legislation to give effect to the notions of port State control.

Under PSC, once a ship voluntarily enters port, it becomes fully subject to the laws and regulations prescribed by the officials of that territory. ${ }^{115} \mathrm{MoUs}$ establish regional PSC organisations responsible for the implementation of PSC measures. ${ }^{116}$ PSC is a cooperative regime that attempts to make PSC procedures uniform in all ports to prevent the diversion of vessels to ports where there are no PSC measures or where a coastal State may be unwilling or unable to exercise PSC measures. Under PSC, the

112 The court found that as the crew members had still been searching for the surviving stowaway when the McRuby entered the French territorial sea, these searches were 'subsequent to the sequestrations and executions and all the facts constituted an indivisible whole. It is common practice in France for the courts to hear matters concerning acts committed outside the country by foreigners, if the acts are indivisible and part of them are undertaken on French territory'. Bardin, A., supra nt. 111, 38. Further, the suspects were detained on French soil and the prosecutor argued that therefore a French court could try them. Nundy, J., "Stowaways 'killed and thrown overboard"', The Independent, 27 November 1994.

113 Yang, H., supra nt. 94, 98.

114 International Maritime Organization, "Port State Control", 2013, available online at $<$ www.imo.org/ourwork/safety/implementation/pages/portstatecontrol.aspx> (accessed 22 June 2013).

115 Hare, J., supra nt. 92.

116 Europe and the North Atlantic are covered by the Paris MoU; Asia and the Pacific are covered by the Tokyo MoU; Latin America is the Acuerdo de Viña del Mar; the Caribbean is the Caribbean MoU; West and Central Africa are the Abuja MoU; the Black Sea region is covered by the Black Sea MoU; the Mediterranean is the Mediterranean MoU; the Indian Ocean is the Indian Ocean MoU; and finally the Gulf Region is covered by the Riyadh MoU. 
power of port States over foreign vessels does not come from international conventions, but from their territorial jurisdiction over the ships in their ports. In this sense, even non-parties to the IMO and ILO conventions can enforce the conventions' provisions by transferring them into their national laws and implementing them against foreign vessels in their ports. ${ }^{117}$ The system of PSC extends coastal State jurisdiction and is potentially important in providing opportunities to intervene in identifying and ending trafficking situations while vessels are in port.

The third category under UNCLOS comprises those areas not in a coastal State's territory but nonetheless where a coastal State may exercise some jurisdiction. These include contiguous zones ${ }^{118}$ (a zone contiguous to a coastal State's territorial sea) and EEZs. In an EEZ, a coastal State has the sovereign right to explore, exploit and protect resources, but not sovereignty over the waters. In other words, because an EEZ is not a coastal State's territory, innocent passage does not apply; in an EEZ, a coastal State may only interfere in the freedom of navigation by a foreign vessel if it can be shown that its activities are prejudicial to the protection of resources. ${ }^{119}$ Under the law of the sea, the enforcement of mechanisms that could be used to prevent and combat the trafficking of seafarers or fishers will depend on the State exercising control over a vessel.

\section{III.4. Building from the Existing Legal and Regulatory Framework}

While international anti-trafficking law, international maritime law and the law of the sea provide a legal framework for the international community to prevent and combat trafficking at sea, significant gaps still exist. How the key obligations of these three bodies of international law work in practice and, equally, how they intersect with one another, is not uncomplicated. The application of anti-trafficking policies and laws within the fishing and seafaring sectors (and across different legal jurisdictions) is complicated by the very specific and distinct nature of fishing and seafaring. And the ways in which the existing legal and regulatory framework for the seafaring and fishing sectors may be relevant for addressing human trafficking has not been extensively explored and tested.

A commitment is needed by States to implement the existing key obligations from international anti-trafficking law, international maritime law and the law of the sea that can be used to combat trafficking. This will require education, assistance, persuasion, promotion, economic incentives, monitoring, enforcement and sanctions, all of which are accompanied by the setting up or improvement of administrations and associated costs. ${ }^{120}$ The quality of current national legislation in many States remains a limiting factor and States need to bring their legislation in line with their obligations

117 Yang, H., supra nt. 94, 98.

118 UNCLOS sets forth that in a contiguous zone, a coastal State may exercise the control necessary to prevent infringement of its customs, fiscal, immigration or sanitary laws and regulations and punish infringement of those laws. The contiguous zone may not extend beyond 24 nautical miles from the baseline, therefore contiguous zones are those between 12 and 24 nautical miles from a baseline over which a coastal State may exercise some jurisdiction. Art. 33 UNCLOS.

119 An EEZ is a sui generis zone where foreign nations maintain most of the rights guaranteed on the high seas. Pedrozo, R., "Which High Seas Freedoms Apply in the Exclusive Economic Zone?", LOS Reports, vol. 1, 2010, 5.

${ }^{120}$ Fisheries and Aquaculture Department, REPORT: Safety at sea as an integral part of fisheries management, FAO Fisheries Circular No. C966, 2001. 
under anti-trafficking law and maritime law (and enforce their laws on their vessels as required by the law of the sea).

States may also potentially exercise jurisdiction over their nationals for crimes they commit or are complicit in wherever they occur. This is an aspect of national law that merits further discussion when exploring the legal and regulatory framework in tackling criminal activities at sea. States can criminalise and prosecute their own nationals' involvement in illegal activities on board foreign vessels in any maritime zone. ${ }^{121}$ The nationality theory of jurisdiction is a well-established means by which a State can claim jurisdiction over extraterritorial conduct. ${ }^{122}$ While a State cannot arrest an individual within the territory of another State, it may arrest its own citizens in a locality that is not within the jurisdiction of any nation, such as the high seas. ${ }^{123}$ And, if extradition treaties are in place, a State may also request that a foreign State arrest and extradite the requesting State's national for prosecution. ${ }^{124}$

This article is a starting point in considering where and how improved policies and regulations may contribute to an improved situation for seafarers and fishers. It is not an exhaustive exploration, but rather a preliminary consideration of what changes may positively impact anti-trafficking efforts in the commercial fishing and merchant fleets. The following sections explore the three P's of anti-trafficking - prevention, protection and prosecution - with attention to how gaps and issues in the legal and policy frameworks (or lack of enforcement) provide space for trafficking exploitation and also limit options and opportunities for remedy. The article also seeks to disentangle the specificities and challenges when considering how to prevent and combat trafficking in the merchant fleet as well as (and in contrast to) the commercial fishing sector. However, it is important to stress that the merchant and fishing industries are dynamic and changing industries and must necessarily be a part of the process of reviewing and amending the legal framework to comprehensively address trafficking at sea. Seafarers and fishers themselves must also be brought into the discussion as they can provide essential information toward making laws more effective and in guaranteeing the protection of their rights.

\section{Prevention}

Discussions of trafficking prevention typically centre on awareness raising and the dissemination of information about trafficking risk connected to migrating and accepting work offers. Underpinning such approaches is the assumption that, in the case of sufficient information about trafficking, potential migrants would not expose themselves to dangerous migration and work situations.

Certainly specific information about trafficking and migration risks is needed in terms of the seafaring and commercial fishing sectors and can, in some cases, prevent risky decision-making that can lead to trafficking. ${ }^{125}$ For example, trafficked seafarers/

121 De Coning, E., supra nt. 24, 26.

122 Blakesley, C., "United States Jurisdiction Over Extraterritorial Crime", Scholarly Works Paper 318, 1982.

123 Clark, P., "Criminal Jurisdiction Over Merchant Vessels Engaged in International Trade", Journal of Maritime Law and Commerce Vol. 11, No. 2, 1980.

124 See, e.g., Model Treaty on Extradition, G.A. res. 45/116, annex, 45 U.N. GAOR Supp. (No. 49A) at 212, U.N. Doc. A/45/49, 1990.

125 This might include information about the specific risk factors for seafarers and fishers (and the differences between the two sectors) as well as advice in researching ships, crewing agencies, placements, and so on. As important is information about avenues for assistance in case of difficulties - e.g. through ITF, port authorities, embassies and so on. Surtees, supra nt. 20. 
fishermen from Ukraine stressed the need for more information about risks as part of the overall education of seafarers in maritime colleges and training programmes to allow for more informed choices and safe, verified placements. ${ }^{126}$

However, information in and of itself is unlikely to be sufficient to prevent seafarers and fishermen from accepting what might be risky placements. The same study from Ukraine noted risk factors that had little to do with lack of information, but rather were a function of constrained work opportunities and life situations. ${ }^{127}$ Certain types of seafarers were particularly vulnerable to offers from unscrupulous crewing agencies - namely those with limited experience, older seafarers who were 'less desirable' on the job market, those facing a financial crisis and those who had been unemployed for some time. ${ }^{128}$ Similarly, in Southeast Asia, where there is an increasing awareness amongst migrants that the fishing sector poses risks and problems, migrant workers continue to accept positions on fishing boats because of constrained economic options and, in some cases, economic aspirations that are at play in migration decision-making. ${ }^{129}$ In addition, some fishers are completely deceived, literally tricked into working on fishing boats, in which case such information is not helpful or relevant.

Moreover, preventive measures that are limited to awareness raising amongst fishers and seafarers unjustifiably rests some responsibility for trafficking crimes on victims. In other words, while awareness raising can be a positive, emphasising awareness raising as the primary approach implies that trafficked persons are primarily responsible for decisions about migration and employment that result in their being trafficked. However, this perspective ignores the responsibility of States to regulate the labour sector, for both domestic and foreign placements, in ways that protect their citizens and prevent them being trafficked.

Currently, in many countries legally registered and licensed crewing agencies are, through a lack of legislation, policy and enforcement, afforded unfettered opportunity to abuse and exploit seafarers and fishers. ${ }^{130}$ There is a need for better regulation of labour recruitment agencies to protect prospective migrants and prevent trafficking. Current recruitment practices facilitate trafficking-for example: the payment of recruitment fees by seafarers/fishers; the practice of offering contracts in languages not spoken by seafarers/fishers; the lack of accountability of crewing agencies and the use of fraud and deception during recruitment. How these practices contribute to trafficking (and how this can be prevented) is discussed in the following sections.

\footnotetext{
126 Surtees, supra nt. 20, 44.

127 Ibid.

128 Idem, 43-47 and De Coning, E., supra nt. 17, 41.

129 See, e.g., Brennan, M., supra nt. 6, 24.

130 Surtees, R., supra nt. 21, 51.
} 


\section{IV.1.Recruitment Fees Borne by Seafarers/Fishers Amplify Trafficking Vulnerability}

Crewing agencies are companies that match seafarers and fishers with ship owners, usually in exchange for a recruitment fee. International standards -including the MLC, ${ }^{131}$ various ILO conventions ${ }^{132}$ and the WIF Convention ${ }^{133}$-prohibit the payment of recruitment fees by seafarers and fishers. Fees are to be borne by the employer.

Yet, the payment of recruitment fees by seafarers and fishers is an entrenched practice in many countries. ${ }^{134}$ The majority of seafarers and fishers trafficked from Ukraine paid recruitment fees varying from 700USD to 1600USD, typically equivalent to one to two months wages promised in their contract (and they generally never received any payment). ${ }^{135}$ Similarly, Indonesian seafarers/fishers sent to the United Kingdom each paid 500USD to their local manning agent in Indonesia to secure their positions. ${ }^{136}$ And Indonesian fishers working on South Korean vessels in the New Zealand EEZ found that they paid high recruitment fees; between $30 \%$ and $50 \%$ of their monthly salary was generally withheld until the successful completion of the contract. ${ }^{137}$

Recruitment fees borne by the individual fisher or seafarer amplify vulnerability in that they bind them to their exploitative situation. ${ }^{138}$ Many seafarers and fishers go into debt to cover recruitment fees and then, as a consequence, feel unable to leave a trafficking situation because they need to repay their debt, which could also be compounded by interest. One Ukrainian seafarer, who was chronically unemployed

131 The MLC prohibits the payment of recruitment fees. MLC Regulation 1.4 states that all seafarers shall have access to an efficient, adequate and accountable system for finding employment on board ship without charge to the seafarer. MLC Standard A1.4 states that States Parties shall, in their laws and regulations or other measures, at a minimum require that no fees or other charges for seafarer recruitment or placement or for providing employment to seafarers are borne directly or indirectly, in whole or in part, by the seafarer, other than the cost of the seafarer obtaining a national statutory medical certificate, the national seafarer's book and a passport or other similar personal travel documents, not including, however, the cost of visas, which shall be borne by the ship owner.

132 Two ILO conventions deal specifically with the regulation of recruitment and placement agencies and prohibit the payment of recruitment fees by seafarers. ILO convention No. 9 is the Placing of Seamen Convention, 1920 and states in Article 2 that 'the business of finding employment for seamen shall not be carried on by any person, company, or other agency, as a commercial enterprise for pecuniary gain; nor shall any fees be charged directly or indirectly by any person, company, or other agency, for finding employment for seamen on any ship' and that laws shall provide punishment for violating this Article. ILO convention No. 179 is the Recruitment and Placement of Seafarers Convention, 1996.

133 The WIF Convention requires that no fees or other charges for recruitment or placement of fishers be borne directly or indirectly, in whole or in part, by the fisher. Art. 22 WIF Convention. However, the WIF Convention is not yet in force and as of May 2013 has only been ratified by two countries.

134 See, e.g., EJF supra nt. 28; ITF Report supra nt. 17; Bloomberg Business Week, Skinner, E., "The Fishing Industry's Cruelest Catch", 23 February 2012, available online at <www.businessweek.com/articles/2012-02-23/the-fishing-industrys-cruelest-catch> (accessed 23 June 2012); and Yea, S., supra nt. 18.

135 Surtees, R., supra nt. 21, 54.

136 International Transport Workers' Federation (ITF), REPORT: Migrant Workers in the Scottish and Irish Fishing Industry: Forced or Compulsory Labour or Plain Modern Day Slavery, 2008, 2.

137 Stringer, C., et al., supra nt. 20, 13.

138 Vulnerability to trafficking created by certain recruitment practices is also discussed in Verité, Fair Hiring Toolkit: What Should You Look For? Identifying Company Risk \& Vulnerability to the Human Trafficking and Forced Labor of Migrant Workers, 2011, available online at <https://www.verite.org/node/695> (accessed 22 June 2013). 
for several years, borrowed 1000USD from the bank to pay the recruitment fee; he used his contract as evidence of his ability to re-pay the debt. ${ }^{139}$ Some recruitment fees and contractual commitments clearly led to debt bondage-for example, one Indonesian fisher signed a contract, which stated that he would owe 3500USD should he leave the boat before completing his contract, far more money than he had at his disposal. ${ }^{140}$

Paying recruitment fees may also result in seafarers and fishers not having resources to negotiate out of their trafficking situation. Some trafficked seafarers/fishers exploited in Russia were offered the option of 'buying their freedom' after they embarked on the vessel and realised the real situation. However, as one man explained, none had the money to do so:
At sea they told us the conditions of the contract, which differed completely from the one we signed in Ukraine... Slavery started literally from the very first day of arrival on board the vessel. When we arrived and they told us about the new conditions, I, as the eldest and more experienced, asked a question: "How can we get home?" We had completely different contract conditions and, since the contract conditions were violated, we were not about to work there. I was told that, if we wanted, there was a boat that could come and take us from the ship for 2000USD. Certainly no seafarer had more than 100 or 200USD with him. That is why we had to agree to stay for the minimum period of time that they offered us. ${ }^{141}$

Debt may also mean accepting another risky or exploitative job offer to repay the debt incurred during a trafficking situation, thus potentially leading to re-trafficking.

Ensuring that recruitment fees are borne by employers rather than seafarers and fishers, should aid in trafficking prevention by eliminating vulnerabilities linked to debt or depleted resources before embarkation. This will require implementation by States of the obligations set forth in the key international instruments on this issuenamely the MLC ${ }^{142}$ and the WIF Convention. ${ }^{143}$ These obligations already exist in international law, although they have not been widely ratified-for example, ILO Convention No. 9, which seeks to eliminate the finding of employment for seamen as a commercial enterprise for pecuniary gain (and the charging of fees for finding employment for seamen), has been in force since 1921 but has only 41 ratifications. ${ }^{144}$ Similarly, ILO Convention No. 179 addresses the recruitment and placement of seafarers and, arguably, also of fishers ${ }^{145}$ but has only ten ratifications. Convention No.

139 Surtees, R., supra nt. 21, 54.

${ }_{140}$ Skinner, E., supra nt. 134. See also Stringer, C., et al., supra nt. 19.

${ }^{141}$ Surtees, R., supra nt. 21, 71.

142 The MLC entered into force on August 20, 2013. As of June 2013, however, the MLC had only 40 ratifications, with Ukraine, Indonesia, Cambodia, Thailand and Myanmar among the countries yet to ratify. ILO, supra nt. 62.

${ }^{143}$ Further ratification of both the MLC and the WIF Convention is also needed. States should ratify these conventions and commit to bringing their national laws in accordance with the important protections they seek to provide to seafarers and fishers.

144 ILO Convention No.9: Placing of Seamen Convention, 10 July 1920, C009, subsequently referred to as ILO Convention No. 9. Ukraine, Indonesia, Cambodia, Thailand and Myanmar have not ratified ILO Convention No. 9.

${ }^{145}$ ILO Convention No. 179 defines a 'seafarer' as 'any person who fulfils the conditions to be employed or engaged in any capacity on board a seagoing ship other than a government ship used for military or non-commercial purposes' and provides that it can be extended (after consultation 
179 states that seafarers should not be subject to fees or other recruitment charges and requires governments to regulate recruitment agencies for seafaring employment ${ }^{146}$ and enact national legislation prohibiting the payment of recruitment fees to crewing agencies by seafarers and fishers. Yet, many countries from which seafarers and fishers originate or are recruited to do not currently have such protections.

Beyond the legal response, an important role can be played by employers and ship owners in prohibiting the payment of recruitment fees by seafarers and fishers to the crewing agencies they use. For example, in its tool kit of fair hiring practices, Verité outlines sample benchmarks of good practice in recruitment and hiring which include, amongst other things, that companies have a written policy, containing enforcement as well as verification mechanisms against workers paying to secure a job and, moreover, do not use brokers, agents or sub-agents that charge recruitment fees. Additional safeguards are that company job advertisements include the statement that no fees shall be charged at any phase of recruitment and hiring, that workers who are charged fees will be repaid and contracts with brokers charging fees are to be terminated. ${ }^{147}$

\section{IV.2.(Non)accountability of Crewing Agencies in Terms of Job Placements can Lead to Trafficking at Sea}

Formal labour recruitment should, in principle, offer a clear and accountable framework through which recruitment and job placements for seafarers and fishers take place. Crewing agencies should offer only placements that live up to the conditions offered at recruitment and outlined in the individual contract. In practice, however, there is enormous scope for abuse and manipulation by crewing agencies due to inadequate legislation surrounding recruitment practices and/or because of weak enforcement of the legal and regulatory framework. ${ }^{148}$

Take, for example, Ukraine, where the Ministry of Labour and Social Policy licenses crewing agencies. While crewing companies must be formally licensed and regularly monitored, in practice the existing mechanism does not provide sufficient safeguards to protect seafarers/fishers against fraudulent recruitment. Crewing companies can be registered in Ukraine fairly easily and monitoring the high volume of crewing agencies in the country is unlikely considering inadequate government staff and resources. ${ }^{149}$ While complaints registered by seafarers and fishers may lead to an investigation and sometimes the suspension of a crewing company's license, industry experts in Ukraine report that this is not inevitable. ${ }^{150}$ This means that if crewing

with the representatives of organisations of fishing vessel owners and fishers or of those of owners of maritime mobile offshore units and seafarers serving on such units) to fishers or seafarers serving on maritime mobile offshore units. ILO Convention No. 179, The Recruitment and Placement of Seafarers Convention, 1996, C179, subsequently referred to as ILO Convention No. 179.

146 ILO Convention No. 179 entered into force in 2000 with 10 ratifications and 8 denunciations. Again Ukraine, Indonesia, Cambodia, Thailand and Myanmar are among the many origin countries to have not ratified ILO Convention No. 179.

147 Verité, Fair Hiring Toolkit, available online at <verite.org/helpwanted/toolkit> (accessed 22 June 2013).

148 In its 2005 Final Report, the International Commission on Shipping found that the issue of manning agents and their recruitment and crew welfare practices 'is a major one' and highlighted the great need to reform and regulate this area. International Commission on Shipping, Final Report: Review of responses to Ships, Slaves and Competition, ICONS, 27 July 2005, 7.

149 Surtees, R., supra nt. 21, 54-55.

150 Ibid. 
companies wish to pursue unethical and illegal practices, there is room and opportunity within the system due to a lack of oversight.

Additionally, under Ukrainian legislation crewing agencies are not responsible or liable for the well-being (or violation of the rights of) of seafarers and fishers whose placement aboard a vessel they arrange. Agencies are not required to assure the work conditions and salaries promised at recruitment, contrary to international standards, ${ }^{151}$ as one seafaring unionist explained:

The crewing company finds the employee for the employer and the employer for the employees. They are just intermediaries...They sign the contract between [the seafarer] and other parties but they are not involved. They are just a connector and that is all. If there are any problems on board or repatriation is needed, they are not dealing with these issues because [they say]: 'We are only looking for a working place for seafarers and fishers and looking for new staff for the employer'. ${ }^{152}$

Even in countries where crewing agencies may be held legally accountable for exploitative or bad placements, contracts and agreements with fishers and seafarers are often arranged in ways that de-incentivise or blatantly prohibit complaints. Consider a contract signed by (an illiterate) Nepalese fisher with a Singaporean recruitment agency in which it explicitly stated that, should the crew member be unhappy with the arrangement or dismissed from the job, he had 'fully understood' that he would not 'claim back any amount of money spent for securing this job' (in other words, the recruitment fee). ${ }^{153}$ While such contracts may (or may not) be legally binding, the legal legitimacy is likely to be unclear to the individual fisher or seafarer, particularly when illiterate, with limited education or not well versed in the law.

Lack of accountability of crewing agencies is at odds with international standards. The MLC Code requires States Parties to have competent authorities closely supervise and control all seafarer recruitment and placement services, and ensure that crewing agency licenses are granted or renewed only after verification that the agency meets the requirements of national laws and regulations. ${ }^{154}$ But for the MLC Code to take effect, States need to ratify the MLC and implement these standards in national law and regulations.

There is also a potential role to be played by ship owners in deciding which crewing agencies they will (and will not) use. Ethical and responsible practice for ship owners vis-a-vis job placement agencies and labour brokers would include employers/ship owners ensuring that crewing agencies they use operate legally, are

151 The MLC Code requires a State to ensure that seafarer recruitment and placement services operating in its territory meet a detailed list of obligations to safeguard seafarers. Under the MLC recruitment agencies are legally responsible for the placement of seafarers and culpable for complaints that arise out of their activities (including being required to establish a system of protection to compensate seafarers for monetary loss that they may incur as a result of the failure of the agency to meet its obligations to them). Standard A1.4 MLC. For fishers, when it comes into force, the WIF Convention will address recruitment and placement services, as well as placement aboard vessels. For example, the WIF Convention sets forth that States shall determine the conditions under which any licence, certificate or similar authorization of a private recruitment or placement service may be suspended or withdrawn in case of violation of relevant laws or regulations and specify the conditions under which private recruitment and placement services can operate. Art. 22 WIF Convention.

152 Surtees, R., supra nt. 21, 55.

153 EJF, supra nt. 28, 13.

154 MLC Standard A1.4. 
certified or licensed by the competent authority and do not engage in fraudulent behaviour that places workers at risk of labour trafficking. This includes performing due diligence checks on the agency involved in hiring and placement and implementing effective measures to ensure the company's legal compliance of subcontractors in each jurisdiction in which they operate. ${ }^{155}$ The difficulty in practice is that this relies on ship owners to wish to (or be legally required to) employ scrupulous and accountable crewing agencies, which is not always the case. Many ship owners and companies also deliberately register their vessels in countries where such requirements are not legally enshrined.

\section{IV.3.Recruitment of Seafarers and Fishers May Involve Fraud and Deception}

Fraud and deception in the recruitment of seafarers and fishers can rise to the level of trafficking if used to recruit individuals for intended exploitation that, at a minimum, includes forced labour or services, slavery or practices similar to slavery. ${ }^{156}$ Trafficked fishers and seafarers have reported fraud and deception in the recruitment process, generally in the form of lies about the severity of work conditions or salary payment. ${ }^{157}$ In some instances, written contracts are not provided, allowing for later changes to and violations of the (verbal) work agreement. Many fishers who embark on fishing vessels in Thailand do not have written contracts; they have made verbal agreements with recruiters, captains or ship owners that are not honoured. ${ }^{158}$ In other cases, seafarers or fishers find at embarkation that contracts will not be honoured and less favourable terms are unilaterally imposed. ${ }^{159}$ In still other instances, seafarers and fishers are forced to sign contracts in a language that they do not understand. ${ }^{160}$ Some individuals are fraudulently recruited for service at sea with no vessel to join-e.g. Indian cadets who paid up to 5000USD to fake manning agents but were left stranded without work upon arrival in the United Arab Emirates. ${ }^{161}$ Some individuals do not even know that they are being recruited for service on a ship. A number of trafficked fishers in Thailand did not know that they would be working on a fishing boat until the broker took them to the pier. ${ }^{162}$

155 Verité, supra nt. 147.

156 Art. 3(a) Trafficking Protocol. Art. 3(b) of the Trafficking Protocol goes on to state 'The consent of a victim of trafficking in persons to the intended exploitation set forth in subparagraph (a) of this article shall be irrelevant where any of the means set forth in subparagraph (a) have been used'. This means that even if a seafarer or fisher 'consents' (e.g. via contract) in the recruitment process to being exploited, if fraud or deception are used by recruiters to achieve such consent with the intent of exploitation, such consent is irrelevant.

157 Vulnerabilities to trafficking created by certain recruitment practices are also discussed in Verité, What Should You Look For? Identifying Company Risk \& Vulnerability to the Human Trafficking and Forced Labor of Migrant Workers, available online at <https://www.verite.org/node/695> (accessed 22 June 2013).

158 Robertson, P., supra nt. 6, 20.

159 This was the case amongst Ukrainian seafarers trafficked to Russia (Surtees, R., supra nt. 21, 71) as well as amongst fishers working in the Scottish fishing industry where the contracts agreed by them were changed after their arrival in the UK. For example, one Filipino man had his salary reduced from 1,100USD per month to 550USD per month without his agreement. ITF, supra nt. 136.

160 Cf. De Coning, E., supra nt. 24; EJF, supra nt. 27; Skinner, E., supra nt. 134 (Indonesian men on South Korean vessel); and Surtees, R., supra nt. 21 (Ukrainian men in Turkey).

161 ITF Report, supra nt. 17, 24.

162 'Brokers will often promise other types of work to migrants, such as work in factories, as well as a high salary to entice migrants to agree to the recruitment.' Robertson, P., supra nt. 6, 19. 

seafarers and fishers.

Under the MLC, terms and conditions of employment must be clearly set out in contracts and freely agreed to by the seafarer. ${ }^{163}$ Similarly, the WIF Convention specifies that a State 'shall adopt laws, regulations or other measures requiring that fishers working on vessels flying its flag have the protection of a fisher's work agreement that is comprehensible to them and is consistent with the provisions of the Convention. ${ }^{164}$ Moreover, it is the responsibility of the fishing vessel owner to ensure that each fisher has a written fisher's work agreement (signed by both the fisher and the fishing vessel owner) that provides decent work and living conditions on board the vessel as required by the Convention. ${ }^{165}$ Under Article 43(1), a flag State that 'receives a complaint or obtains evidence that a fishing vessel that flies its flag does not conform to the requirements of the Convention shall take the steps necessary to investigate the matter and ensure that action is taken to remedy any deficiencies found. ${ }^{166}$ This highlights the need for all countries (but perhaps most pressingly for flag States and countries where recruitment takes place) to ratify international treaties and codify these protections in national law. As critical is the enforcement of national legislation as a potential means of trafficking prevention.

Ship owners and employers must also be engaged in 'prevention'; they can be central in ensuring that they do not employ persons who have been deceived, thereby becoming complicit in recruitment abuses that may constitute human trafficking. They should ensure that they comply with the requirements of the MLC or WIF Convention (depending on the type of vessel they own/operate) and ensure that, prior to deployment, all workers are provided a signed copy of their original contract, in a language they understand. Ship owners and employers should also explain the terms and conditions of the contract and have the means to verify that said terms are clearly understood and fully agreed to by workers. When initial contracts are to be signed with crewing agencies, the ship owner/employer must ensure that the details of working conditions described at recruitment are consistent with the details contained in the employment contract at the time of hiring and with actual job conditions and responsibilities. Moreover, ship owners/employers should implement a policy that prohibits the substitution of original contract provisions with those less favourable to the worker. Any amendments made to improve conditions should be made with the knowledge and the informed, written consent of the worker. ${ }^{167}$

Practical tools can also potentially be helpful in preventing the deception and fraud of prospective fishers and seafarers. Tools or programmes that allow seafarers and fishers to check the legality, authenticity and background reports of their proposed placements may play an important role in preventing trafficking. At a minimum, such tools should allow seafarers/fishers to view images of the ship and its current licenses, check its location, establish whether there have been complaints or lawsuits filed by previous crew, check the legality of the contract and check the history and reliability of placement firms. Existing tools include the ITF vessel registry, the Equasis project (an information system developed jointly by the European Commission and the French Maritime Administration that collects existing safety-related information on ships) and

163 Regulation 2.1 of the MLC stipulates that: 1) The terms and conditions for employment of a seafarer shall be set out or referred to in a clear written legally enforceable agreement and shall be consistent with the standards set out in the Code and 2) Seafarers' employment agreements shall be agreed to by the seafarer under conditions which ensure that the seafarer has an opportunity to review and seek advice on the terms and conditions in the agreement and freely accepts them before signing.

164 Art. 16 WIF Convention.

165 Art. 20 WIF Convention.

166 Art. 43(2) WIF Convention.

167 Verité, supra nt. 147. 
the FAO's Global Record of the Fishing Fleet. These and similar initiatives should be incorporated into verification systems and awareness of them increasingly disseminated amongst seafarers and fishers-including through maritime schools/colleges, unions, seafaring missions and so on. Finally, on-board complaint mechanisms should be established to allow for the fair, effective and expeditious handling of complaints by seafarers and fishers. ${ }^{168}$ These practical tools can also be used by States in furthering their monitoring efforts. ${ }^{169}$

\section{Protection}

Protection typically refers to a range of interventions starting with identification through various stages of assistance and toward long term recovery and sustainable (re)integration. Initial identification of trafficked persons, in some cases, involves their removal from their trafficking situation and, in other cases, follows their exit from trafficking. Once identified, trafficked persons are to be offered (voluntary) assistance and support, which may be available abroad and/or at home. The Trafficking Protocol provides for the assistance to and protection of trafficking victims in Article 6. In addition to requiring States Parties to endeavour to provide for the physical safety of victims of trafficking while they are within their territory, the Trafficking Protocol recommends that States implement measures to provide for the physical, psychological and social recovery of victims of trafficking in persons. ${ }^{170}$ Other instruments, not least the Council of Europe Convention, go further than the Trafficking Protocol in requiring that States actively identify and assist trafficked persons. ${ }^{171}$

Failure to identify and assist trafficked seafarers and fishers means their exposure to on-going risk and problems. A study of trafficking in the fishing sector in Thailand found that many trafficked fishers escaped on their own, without intervention or subsequent assistance. ${ }^{172}$ These self-rescues involved either jumping overboard and swimming away (either near shore or further out and with the hope of being picked up by another ship); running away when the boat came into port; or, in some cases, sabotaging the vessel or overpowering the captain and commandeering the boat to come into port. ${ }^{173}$ Similarly, Ukrainian seafarers and fishers were identified generally only after seeking out intervention on their own-e.g. from law enforcement in ports,

168 The MLC obligates States Parties to require ships flying their flag to have on-board procedures in place for the handling of complaints by seafarers. Reg. 5.1.5 MLC.

169 Surtees, supra nt. 21, 125. Lloyd's List, a leading daily newspaper for the maritime industry, is another tool that could potentially be used toward trafficking prevention in that it provides information about all aspects of shipping and could, in principle, be used to convey current information about vessels and inspections, information that can impact flag ship owners and operators. See Lloyd's List, available online at <www.lloydslist.com/11/> (accessed 11 August 2013). Lloyd's List provides current information about vessels that could be used by individual seafarers, unions, States or even crewing agencies to monitor the conditions and activity of ships and the results of inspections.

170 Art. 6 Trafficking Protocol. As discussed above, under the CoE Convention the assistance and protection of victims is required.

171 Arts. 10-16 CoE Convention.

172 UNIAP, supra nt. 32.

173 Robertson, P., supra nt. 6, 27 and UNIAP, Exploitation of Cambodian Men at Sea, SIREN series CB02, 2007, available online at <no-trafficking.org/reports_docs/siren/SIREN\%20CB02\%20Exploitation $\% 20$ of $\% 20$ Cambodian $\% 20$ men $\% 20$ at $\% 20$ sea.pdf $>$ (accessed 28 November 2013). 
the ITF and so on-in spite of having come into contact with authorities while trafficked at sea. ${ }^{174}$

Trafficking at sea often means different things in terms of how identification and assistance may (or may not) take place and by whom. In the case of trafficked seafarers and fishers, the governments that have legal and regulatory responsibilities that can be brought to bear on this crime would be flag States, coastal States and port States as well as the trafficked persons' countries of origin. Therefore, the protection of trafficked seafarers and fishers involves different legal and regulatory frameworks and also different institutions than for trafficked persons exploited on land, which will require increased engagement of authorities and frameworks in terms of ensuring identification of and assistance to trafficked persons.

Identifying and assisting trafficked seafarers and fishers also requires a better understanding of the opportunities (and limitations) presented by flag State responsibility, coastal State responsibility and Port State Control (PSC) as well as various external entry points for and barriers to intervention. What follows is a consideration of some of the barriers and problems in the identification and assistance of trafficked seafarers and fishers as well as, wherever possible, suggestions of measures that might offer some form of protection. The following discussion explores issues of identification on the high seas; in territorial waters and EEZs; in ports; and in 'destination countries', beyond ports. It also explores the, to date, inadequate provision of assistance to trafficked seafarers and fishers- both abroad and at home.

\section{V.1. Inadequate Identification of Trafficked Seafarers and Fishers on the High Seas}

Identification of trafficking cases at sea is difficult precisely because it takes place on the high seas and, therefore, is essentially "out of sight". Some vessels spend months and even years at sea. ${ }^{175}$ Many of the Ukrainian seafarers/fishers trafficked to Russia were on vessels that never entered ports. ${ }^{176}$ In Thailand's deep-sea fishing industry, trafficked fishers routinely spend a year or more on fishing vessels beyond Thailand's territorial waters. They are sometimes moved between vessels while at sea to meet crewing needs. ${ }^{177} \mathrm{~A}$ deputy boat captain on a Thai fishing vessel reported, 'Once a captain is tired of a guy, he's sold to another captain for profit. A guy can be out there for ten years just getting sold over and over. ${ }^{178}$ Further, ship owners and captains may be well-versed in how to evade the authorities, moving between different

174 Surtees, R., supra nt. 21, 97.

175 Brennan, M., supra nt. 6; Cf. De Coning, E., supra nt. 17; De Coning, E., supra nt. 25; EJF supra nt. 16; EJF supra nt. 28; Robertson, P., supra nt. 6; Verité, supra nt. 24; and Yea, S., supra nt. 18.

176 There are reports that large numbers of fishers are kept in 'work camps' on board derelict vessels, functioning as mother ships to fleets of fishing vessels, some 200 nautical miles off shore. EJF supra nt. 28.

177 UNIAP, supra nt. 32, 5. See also The Asia Foundation, Bollinger, K. and McQuay, K., Human Trafficking Rampant in Thailand's Deep-Sea Fishing Industry, 2012, available online at $<$ http://asiafoundation.org/in-asia/2012/02/08/human-trafficking-rampant-in-thailands-deep-seafishing-industry/> (accessed 22 June 2013); Brennan, M., supra nt. 6; EJF supra nt. 16; EJF supra nt. 28; and Robertson, P., supra nt. 6.

178 Winn, P., "Desperate Life at Sea", Labour Rights Promotion Network, 21 May 2012. The inability to escape the sea and the psychological effects of never setting foot on land while trafficked (sometimes for years) are complicating factors that must be considered in the assistance of identified trafficked seafarers and fishers and efforts should be made to tailor assistance to the unique needs of trafficking victims rescued from sea. 
jurisdictions - from the high seas to the territorial waters of different countries as well as in and out of EEZs ${ }^{179}$ — and to ports with lax control.

Some ship owners/vessels make a conscious effort to remain out of sight to avoid coming into contact with the authorities-e.g. because they are engaged in IUU fishing, have substandard vessels, 'employ' trafficked crew members and so on. In other instances, being out of sight is, at least in part, a function of how fishing is increasingly taking place far out at sea, due to depletion of fish stocks closer to shore. Many fishing vessels are equipped to stay at sea for prolonged periods of time, with food, fuel and supplies, and sometimes even crew brought aboard at sea via supply vessels. Many high seas fishing vessels tranship their catches to refrigerated cargo vessels while at sea and depend on at-sea refuelling and resupply vessels to allow them to fish longer and at lower costs. ${ }^{180}$

While trafficked seafarers and fishers are generally out of sight while at sea, there are nonetheless some potential opportunities for identification worth pursuing, but the system of flag State responsibility means that these entry points will frequently depend on the willingness of the flag State to monitor vessels on its registry and to allow opportunities for identification through inspection to occur. Flag States have primary jurisdiction over vessels on the high seas; they are obliged to take any steps necessary to secure observance with international regulations, procedures and practices. ${ }^{181}$ Thus, in terms of human trafficking, the flag State needs to assume responsibility for duties to identify and assist victims of trafficking. Indeed there are very few instances in which it would be legally permissible for a vessel to be boarded while on the high seas, without the consent of the vessel operator, who is under the jurisdiction of the flag State. ${ }^{182}$ One respondent interviewed for a study of exploitation aboard FCVs in the New Zealand EEZ, when asked why abused crew did not complain to port State authorities, focused on the issue of flag State jurisdiction: 'in raising health and safety issues especially on Korean vessels... [you are] told [you] are on Korean soil and there's nothing we can do about it.' ${ }^{183}$

As has been discussed, enforcement of flag State responsibility is weak. Flag States generally fail to enforce their laws when crimes are committed against the environment or people. Further the IMO does not have enforcement power and cannot sanction a State for failing to exercise jurisdiction over a vessel on its register and/or meet its responsibilities under IMO conventions. In general, the conventions adopted under the aegis of the IMO provide for reporting obligations of States Parties but the IMO has no further control or enforcement functions. ${ }^{184}$

179 Surtees, supra nt. 21, 84-85.

180 At-sea transhipment, resupply and refuelling is not, for the most part, illegal. However, as part of fishing operations, they are often unregulated (a number of States regulate at- sea transhipments). At least some vessels in these fleets provide services to IUU fishing fleets as well as legitimate fishing fleets. Gianni and Simpson, supra nt. 17, 4.

181 Hare, J., supra nt. 91; Hare, J., supra nt. 92.

182 UNCLOS Article 94(2)(b) requires the flag State to assume jurisdiction not only over ships flying its flag, but also over the master, officers and crew of such ships. Article 94 is recognised as a basis for the flag State exercising jurisdiction over the skipper, officers and crew of fishing vessels. Hosanee, N., A Critical Analysis of Flag State Duties as Laid Down Under Article 94 of the 1982 United Nations Convention on the Law of the Sea, Division for Ocean Affairs and the Law of the Sea Office of Legal Affairs, 2009, 26.

183 Stringer, et al., supra nt. 20, 11.

184 The STCW Regulation I/7 provides for an exception to the rule in that it directs that the IMO, on the basis of information to be provided by Member States, establish a so-called 'white list' of States deemed to comply fully with the requirements of the STCW; thus a control function is given to the IMO with regard to implementation of the STCW. However, the only real control possibility the 
Flags of convenience (FoCs) and flags of non-compliance (FoNCs) pose a particular challenge to meaningful flag State responsibility and, by implication, the identification of trafficked seafarers and fishers. Vessels flying under FoCs are, arguably, more likely to employ poor labour practices and potential trafficking situations are not likely to be monitored, identified or prosecuted. And, while in the seafaring sector the lack of flag State law enforcement is, to some extent, compensated by the PSC regime when vessels come to port, there is a lack of an international legal framework for the safety or working conditions of fishers on board fishing vessels, including in ports ${ }^{185}$ An additional complication in the case of FoCs is the lack of a 'genuine link' between ship owner and flag State (as specified in article 91 of UNCLOS), making it difficult for the flag State to exercise any jurisdiction over a company with no assets or personnel in its territory. A genuine link would mean that a ship owner has some presence in the flag State in terms of assets and resources to hold them accountable for violations of international law. ${ }^{186}$

In other cases, inadequate enforcement of flag State responsibility is due to a lack of resources or capacity. This is especially likely to be the case for less developed countries or new registries, which may need the assistance of other States to enforce flag State obligations. Consider Mongolia, a landlocked country, which, since opening its registry in 2003, has registered more than 1,600 ships to its flag. ${ }^{187}$ While Mongolia has partnered with Singapore to facilitate its registry, questions arise as to how a State without a port and with its registry based in a different country can ensure the inspection and monitoring of ships flying its flag, particularly when the Maritime Law of Mongolia states that 'the board of vessels flying the State flag of Mongolia shall be in exclusive jurisdiction of Mongolia'. ${ }^{188}$ Another example is Thailand, where the Department of Fisheries (DoF) under the Ministry of Agriculture and Cooperatives (MoAC) is responsible for licensing types of fishing gear and equipment, delimiting how the gear is used and setting methods for and areas where types of equipment can be used. However, according to a study of trafficking on Thai fishing vessels, inspections and monitoring rarely take place. ${ }^{189}$

Even if a flag State is willing and able to meet its obligations under IMO and ILO treaties, there may be practical constraints in terms of when/how human trafficking can realistically be observed and whether vessels that employ trafficked labour would be surveyed and inspected. For example, in the fishing industry, a number of States

IMO has, which is the establishment of the list, should not be overestimated. Witt, J., Obligations and Control of Flag States, LIT VERLAG Dr.W.Hopf, 2007, 207.

185 De Coning, E., supra nt. 17, 57.

186 ITF Report, supra nt. 17, 10-11. To address the problems of FoCs, in 1948, the ITF launched the FoC campaign. The FoC Campaign has two elements: (1) a political campaign aimed at eliminating the flag of convenience system by achieving global acceptance of a genuine link between the flag a ship flies and the nationality or residence of its owners, managers and seafarers and (2) an industrial campaign designed to ensure that seafarers who serve on flag of convenience ships, whatever their nationality, are protected from exploitation by ship owners. The ITF's maritime unions have developed a set of policies that seek to establish minimum acceptable standards for seafarers working on FoC vessels. Currently, approximately one third of all FoC vessels are covered by ITF agreements, thus giving direct protection to well over 150,000 seafarers. See ITF, About the FoC Campaign, available online at <http://www.itfseafarers.org/FOC_campaign.cfm> (accessed 23 June 2013).

187 Mongolia Ship Registry, available online at <www.mngship.org/> (accessed 23 June 2013).

188 Art. 3.2 Maritime Law of Mongolia, May 28, 1999.

189 Robertson, P., supra nt. 6, 13. 
require the presence of observers ${ }^{190}$ on board licensed fishing vessels who, in principle, would be well positioned to observe and report on problems in the vessel's living and working conditions. However, one recent study of organised crime within the fishing industry found that individuals likely to interact with trafficking victims on board fishing vessels, such as fisheries observers, were unaware that forced labour conditions might amount to human trafficking, ${ }^{191}$ and such issues are generally considered beyond the scope of their work. According to a spokesman for the government of New Zealand, observers are not formally tasked with assisting abused crew, although they may report abuses to the Department of Labour. In some cases, when fishers have reported abuses to New Zealand observers, they were told that this was not a part of their job. ${ }^{192}$ Moreover, observers are often poorly paid and may be bribed or threatened while on board the vessel, which they generally are for prolonged periods of time. ${ }^{193}$

In the merchant sector, marine surveyors inspect the safety of vessels and on-board conditions but generally do not travel with the vessel to sea, thereby limiting opportunities to interact with crew. They might occasionally be in a position to identify trafficking ${ }^{194}$ - for example, when interacting with (and even interviewing) crew while conducting inspections in port. However, there are no established international guidelines to determine the certification of marine surveyors, which raises questions about universal capacity. ${ }^{195}$ Flag States also generally contract surveying out to local classification or non-exclusive marine surveyors, which may

190 A fisheries observer (sometimes called a scientific observer) is an independent specialist who serves on board commercial fishing vessels or in fish processing plants and other platforms and is employed by a fisheries observer programme, either directly by a government agency or by a third party contractor. Observers spend anywhere from one day to three months out at sea before returning to be 'debriefed'. A debriefing consists of reviewing any unusual occurrences or observations, violations observed, and any safety problems or other hardships they endured during the trip. These data are then integrated into the regional agency's database used to monitor fish quotas. See, e.g., Association for Professional Observers, available online at <http://www.apo-observers.org/> (accessed 23 June 2013).

191 De Coning, E., supra nt. 17, 57.

192 Skinner, E., supra nt. 134. That being said, the MLC, which entered into force in August 2013, aims to have inspections (by both flag State and port State officials) that will include interviews with crew. That is, compliance and enforcement obligations for both flag and port States involve vessels earning a Maritime Labour Certificate, certifying that they have been inspected and verified to be in compliance with the Convention requirements. Certification will require a new approach from the flag State inspection regime, including the training of inspectors in how to examine crew agreements, interview crew members about their contracts and inspect a range of additional fields, such as accommodation and food. In practice, 'the company systems and procedures will be placed under the microscope, as never before'. Grey, M., The Maritime Labour Convention - Shipping's "Fourth Pillar", available online at <http://www.seafarersrights.org/seafarers-subjects/maritime-labourconvention-mlc/> (accessed 23 June 2013). For fishers it seems likely that if the WIF Convention comes into force, regulations to implement its obligations would include similar measures.

193 See, e.g., Public Employees for Environmental Responsibility, High Seas Harassment of Fisheries Observers More Than Doubles: Nearly One in 5 Victimized Yearly, 160\% Jump Since 2007 Yet Few Cases Prosecuted, 16 May 2013, available online at <www.commondreams.org/newswire/2013/05/16-3> (accessed 3 June 2013).

194 There are generally four types of marine surveyors: government surveyors who can be flag State or port State representatives; classification surveyors who can be a representative or inspector of ships; private surveyors (generally hired by marine insurance companies) who examine ship cargo, on board conditions, fuel quality, investigate accidents, and prepare reports; and yacht and small craft surveyors who specialise in smaller vessels, power and recreational sailing. See Marine Surveyor Services, available online at <www.marinesurveyors.com/tools/marine-surveyor-services/> (accessed 23 June 2013).

195 Cf. Hare, J., supra nt. 91; Hare, J., supra nt. 92; and Society of Accredited Marine Surveyors, available online at <www.marinesurvey.org/faqs.html> (accessed 23 June 2013). 
raise a conflict of interest when the ship owner is at least indirectly paying the surveyor. ${ }^{196}$ There are also logistical challenges in terms of what is feasible for surveyors to be able to identify on a large ship working under time pressures from owners and charterers. ${ }^{197}$

Additional barriers to identification by observers include lack of a common language for communication and issues of trust, with seafarers or fishers likely uncertain as to whether disclosure will lead to rescue or might instead mean being left in the hands of the captain and controllers on-board. Trafficked fishers and seafarers may also have concerns about not being paid, should they self-identify as abused or trafficked and ask for assistance. This is especially likely given that payment is often withheld until the completion of a contract. In one case, an Indonesian man trafficked aboard a South Korea-flagged ship was coerced by an agent into signing a contract in English, which he did not understand, under which he surrendered thirty percent of his salary, which the agency would hold until completion of the work. The contract further stipulated that he would be paid nothing for the first three months and, if the work was not completed to the company's satisfaction, he would be sent home and charged more than $\$ 1,000$ in airfare. ${ }^{198}$

Moreover, it is unlikely that vessels with trafficked seafarers or fishers will operate with an observer and/or use a marine surveyor, due to involvement in fisheries crime, lack of a license, substandard vessel conditions or otherwise. ${ }^{199}$ This means that for some (and perhaps many) trafficked fishers and seafarers, their main avenue for identification and assistance rests with a flag State, which may do little or nothing to offer them protection.

\section{V.2. Barriers to the Identification of Trafficked Seafarers and Fishers in Territorial Waters and EEZs}

While generally out of sight, merchant and fishing vessels do nonetheless come into contact with various coastal authorities-for instance, coastguards, the navy and border officials. A coastal State can exercise its rights and jurisdiction under Articles 56 and 73 of UNCLOS to prevent infringement of its laws by ships sailing in its territorial waters - for example, by regulating the activities of foreign vessels in its waters to protect its own interests. ${ }^{200} \mathrm{~A}$ coastal State also has sovereign rights over resources in its EEZ and, therefore, can impose strict fishing regulations, including policies about fishers' right and working conditions while fishing within the EEZ. ${ }^{201}$

However, depending on institutional jurisdiction, the focus of authorities' monitoring efforts may be on issues other than human trafficking-e.g. IUU fishing, pollution or other such violations. For example, Ukrainian seafarers were, on at least one occasion, stopped by maritime authorities, but these officials were concerned with the ship and its catch, missing the opportunity to identify these trafficked

196 Hare, J., supra nt. 91.

197 Hare, J., supra nt. 91; Hare, J., supra nt. 92.

198 Skinner, E., supra nt. 134. See also Stringer, C., et al., supra nt. 20.

199 De Coning, E., supra nt. 17, 113.

200 In 2007, United Nations Office of Legal Affairs, Division for Ocean Affairs and the Law of the Sea advised New Zealand that FCV activities can be regulated by the coastal State in accordance with Article 62(4) of UNCLOS, since the list contained in that provision was not exhaustive. Stringer, C., et al., supra nt. 20, 9.

201 De Coning, E., supra nt. 17, 38. The Work in Fishing Recommendation (WIF Recommendation) of 14 June 2007, International Labour Organization, No. 199 calls upon coastal States to require compliance with WIF when issuing licenses to fish in their EEZ. Art. 55 WIF Recommendation. 
seafarers/fishers. ${ }^{202}$ This highlights the need for a greater awareness of (and commitment to addressing) human trafficking in the commercial fishing and seafaring industries including in terms of training and providing tools to intervene in trafficking cases - e.g. screening tools, translators, legal authority, a specialised toolkit for routine at-sea inspections and so on. In addition, lower ranking crew members generally do not have contact with law enforcement authorities (and this seems especially likely for those who are trafficked and exploited). Generally, senior officers are interviewed when coast guards conduct routine inspections at sea and the issue of human trafficking (or labour abuse in general) is not a part of the standard questions used by law enforcement during such inspections.

As has been mentioned, language barriers between seafarers/fishers and persons who might identify them as trafficked (or at least in need of assistance) are a complicating factor. Without a common language, it is difficult for authorities to screen for vulnerability and risk. It is equally difficult for seafarers or fishers to ask for assistance or to comprehend identification or assistance offers. ${ }^{203}$ Tools are needed for broader communication across (often multiple) language barriers. Coast guards and other authorities are increasingly accompanied by interpreters when boarding vessels, although interpreters are not always available in resource-poor countries and even when interpreters are available, the crew may speak a dialect or language not within the interpreters' range of proficiency. At a rudimentary level, addressing language barriers might involve a list of translated phrases for screening, which would allow seafarers and fishers to request assistance. More sophisticated (although costly) responses could involve the use of audio and/or video technology to reach different nationalities and overcome language barriers. ${ }^{204}$

However, even when law enforcement attempts to screen for human trafficking aboard vessels in territorial waters, trafficked seafarers and fishers may not feel able to speak out, even if interviewed individually and separate from their exploiters. They may, for example, fear being arrested for their involvement in any illegal activities on board. One Ukrainian seafarer/fisher trafficked to Russia described his vessel being detained by Russian authorities but being unable to seek help because the authorities were concerned with illegal catch and not the men's situation. ${ }^{205}$ The possibility that the crew has been forced to engage in the ship's illegal activities must be considered by law enforcement personnel in terms of how seafarers/fishers are approached, their situation understood and interventions undertaken.

Another issue is that trafficked seafarers and fishers may, quite reasonably, fear being left in the hands of their traffickers after disclosing abuse and trafficking, particularly in countries with corruption. Corruption (or fear of corruption) will impact decisions about whom to approach for assistance in leaving a trafficking situation as well as which authorities one is able or willing to trust. One trafficked Ukrainian seafarer explained how he opted not to approach authorities whom he believed were complicit in the illegal crabbing operation into which he was trafficked and, thus, unlikely to help him. Another trafficked Ukrainian seafarer described how men who had fled the vessel when it was in port had been brought back by local law enforcement authorities:

202 Surtees, supra nt. 21, 84.

203 Surtees, supra nt. 21, 85.

204 Idem, 127.

205 Idem, 84. 
It was slavery-like conditions; people could not stand it any longer and tried to escape to the shore. But these criminals had it all covered there because the local police caught the seafarers [who escaped] and brought them back to the ship. ${ }^{206}$

One study also noted that, while some fisheries enforcement officials had observed that fishers on some of the fishing vessels they inspected seemed to be living and working under 'slave-like' conditions, they had not considered this in the context of human trafficking. Moreover, many fisheries officials said that it was outside of their mandate to investigate instances of human trafficking. ${ }^{207}$ That is, the law of the sea provides that a coastal State does not have sovereignty over the exclusive economic zone but only sovereign rights over the marine living resources in the area. The primary jurisdiction relating to the well-being of the crew rests with the flag State.

Another constraint for coastal State authorities in identifying and protecting trafficked seafarers/fishers is limited resources. For example, in Thailand, the Royal Thai Marine Police (RTMP) is the lead law enforcement agency at sea, with authority to board and search vessels in coastal waters and should, ideally, have a prominent role in identifying instances of human trafficking on fishing boats. However, the RTMP are under-resourced, with inadequate budgets for maintaining and operating their patrol boats. One recent study found that the Songkhla Marine Police, purportedly one of the most active squadrons in suppressing trafficking of fishers, only has fuel to run each boat for seven to eight hours per month. ${ }^{208}$

That being said, there is evidence of coastal States taking action to protect fishers and seafarers in territorial waters. For example, in Myanmar, under the terms of a fishing concession between the Government of Myanmar and the Government of Thailand, all crew on Thai fishing boats in Myanmar territorial waters (with the exception of the captain and his top officers) are required to be Myanmar nationals with a Myanmar identification card. The Myanmar Navy inspects Thai fishing boats before allowing them to fish in its territorial waters and compiles a crew list. Upon leaving Myanmar territorial waters, the boat is again inspected and, if any injuries or crew disappearances are identified, the captain is liable for significant fines. ${ }^{209}$

Similarly, in New Zealand the government initiated a parliamentary inquiry into the operation of FCVs in 2011 following research into and media attention on cases of labour violations and human trafficking on FCVs in New Zealand's EEZ. Based on inquiry findings, ${ }^{210}$ the Government decreed that from 2016, commercial fishing vessels operating in New Zealand waters must be registered as New Zealand ships and carry the New Zealand flag. ${ }^{211}$ Flagging vessels to New Zealand can be important as foreign crew will therefore be protected by New Zealand laws including those related to employment and maritime safety. ${ }^{212}$

\footnotetext{
206 Idem, 86.

207 De Coning, E., supra nt. 17, 57.

208 Robertson, P., supra nt. 6, 15.

209 Robertson, P., supra nt. 6, 28-29.

210 New Zealand Ministry of Agriculture and Forestry, Report of the Ministerial Inquiry into the use and operation of Foreign Charter Vessels, 2012, available online at $<$ fish.govt.nz/NR/rdonlyres/1CD50F2C-5F55-481D-A3CB9A7EC25CBE54/0/2012foreignchartervesselsreport.pdf $>$ (accessed 26 October 2013).

211 Some vessels will be exempted from this requirement, arguably weakening New Zealand's efforts to combat trafficking at sea. Harre, T., supra nt. 20.

212 Gallagher, A., supra nt. 19.
} 
Another potential means by which coastal States may improve opportunities to identify trafficked fishers would be to require that fishing vessels licensed to fish in a State's EEZ tranship in port in order to monitor catch and landings. In addition to aiding detection of illegal fishing, this may serve to increase fishers' opportunities to leave a trafficking situation and contact authorities for assistance. A number of States have already implemented such measures. ${ }^{213}$

\section{V.3. Barriers to Identification in Ports}

Ports constitute one of few places where trafficked seafarers and fishers might have access to external authorities that may be able to identify and assist them. This would include port authorities and the port State control regime. It would also, in some cases, include external stakeholders working on the welfare of seafarers and fishers e.g. International Transport Workers Federation (ITF) inspectors, ${ }^{214}$ seafarer associations or unions and seafarer centres (e.g. Mission to Seafarers). ${ }^{215}$

Port State Control (PSC) can be an important means of oversight when vessels come into port, particularly in the absence of flag State enforcement and oversight. Under PSC, port States exercise their territorial jurisdiction over foreign vessels in their ports. PSC ensures compliance with international safety regulations and labour standards in merchant shipping. It is carried out through regionally coordinated Memoranda of Understanding (MoUs); MoU members share information, set inspection targets and cooperate on enforcement. ${ }^{216}$ However, unseaworthy vessels or those engaged in illegal activities undermine the PSC system by moving to ports with lax control and law enforcement regimes - a problem known as displacement. ${ }^{217}$

PSC is normally based on SOLAS and STCW and, therefore, fishing vessels are normally not covered by the PSC regime. While some port States do conduct unilateral PSC of fishing vessels, this is mostly uncoordinated among port States. ${ }^{218}$ Fishing vessels are also not covered by the International Ship and Port Facility Security Code (ISPS Code), which is a comprehensive set of measures to enhance the security of ships and port facilities, ${ }^{219}$ which, in turn, means that no security clearance

213 De Coning, E., supra nt. 25, 39.

214 The ITF represents the interests of seafarers worldwide, of whom over 600,000 are members of ITF affiliated unions. The ITF Seafarers Section maintains a network of over 100 ITF inspectors around the world. See ITF Seafarers, available online at <itfseafarers.org/> (accessed 26 October 2013).

215 Seafaring centres provide a range of outreach services and may be particularly useful for antitrafficking efforts. For example, the Mission to Seafarers runs centres in over 100 ports where seafarers can contact home, receive assistance with problems faced and get a break from life on board ship. Mission to Seafarers, available online at <missiontoseafarers.org/about-us> (accessed 26 October 2013).

${ }^{216}$ De Coning, E., supra nt. 25, 25.

217 Ibid.

218 Ibid. and Surtees, R., supra nt. 6, 87.

219 The ISPS Code was developed in response to the perceived threats to ships and port facilities in the wake of the 9/11 attacks in the United States. The ISPS Code is implemented through SOLAS chapter XI-2 Special measures to enhance maritime security. The purpose of the Code is to "provide a standardised, consistent framework for evaluating risk, enabling Governments to offset changes in threat with changes in vulnerability for ships and port facilities through determination of appropriate security levels and corresponding security measures.' International Maritime Organization, International Convention for the Safety of Life at the Sea (SOLAS) XI-2 and the International Ship and Port Facility Security Code, available online at <imo.org/OurWork/Security/Instruments/Pages/ISPSCode.asp> < (accessed 26 October 2013). 
is needed for fishing vessels and, by implication, fishers are not afforded the same protections as seafarers. ${ }^{220}$

That being said, a number of States inspect and control vessels' compliance with fisheries management conservation regulations, either as part of their national plans of action to prevent, deter and eliminate IUU fishing (NPOA-IUU) or through their participation in Regional Fisheries Management Organizations (RFMOs). And the Agreement on Port State Measures to Prevent, Deter and Eliminate Illegal, Unreported and Unregulated Fishing (PSMA) is expected to soon receive sufficient ratifications to come into force. ${ }^{221}$ PSMA contains various provisions that may serve to augment opportunities to identify trafficked fishers-e.g. provisions on the entry of fishing vessels into port including pre-entry notification (Article 8), in-port inspections (Article 12) and requisite designation of ports for landing fish (Article 7). ${ }^{222}$

Under the WIF Convention, port States will also be able to exercise jurisdiction through the Port State Control provisions contained in Part VII. For example, Article 43 allows a State in whose port a fishing vessel calls in the normal course of its business or for operational reasons, to take action if it receives a complaint or obtains evidence that such a vessel does not conform to the requirements of the WIF Convention. Such a complaint may be submitted by a fisher, a professional body, an association, a trade union or, generally, any person with an interest in the safety of the vessel, including an interest in safety or health hazards to the fishers on board. ${ }^{223}$ Breaches of the WIF Convention include: unsanitary accommodation, catering, and ablution facilities; inadequate ventilation, air conditioning, or heating; and, substandard food and drinking water. ${ }^{224}$

However, seafarers and fishers do not automatically come into contact with port authorities, particularly if they are prevented from leaving their vessel. Access to port is often hampered by international security regulations, which may require foreign crew to stay on board the vessel whilst in port. ${ }^{225}$ Immigration restrictions-i.e. being required by the port State's national law to possess a transit or entry visa for the port of call—may also prevent seafarers and fishers from being able to disembark. Moreover, hundreds of seafarers and fishers move in and out of ports each day making the sheer volume of workers an obstacle to identification. ${ }^{226}$

In addition, PSC inspections are more likely to occur when there already appear to be issues with a vessel-e.g. conditions that would trigger inspections, a complaint being launched and so on. Even when vessels are under scrutiny of the authorities, it may not be the most exploited individuals who are interviewed, as the authorities will generally communicate with those of higher seniority.

For counter-trafficking purposes, interviews with crew in ports would only be useful if port authorities had a sufficient understanding of the indicia of forced labour

220 Surtees, R., supra nt. 21, 87.

221 The PSMA will enter into force thirty days after the date of deposit with the Director-General of FAO of the twenty-fifth instrument of ratification, acceptance, approval or accession. It currently has 23 signatures. Art. 29 Agreement on Port State Measures to Prevent, Deter and Eliminate Illegal, Unreported and Unregulated Fishing of 23 November 2009, FAO, subsequently referred to as PSMA. See also Fisheries and Aquaculture Department, Port State Measures Agreement, available online at $<$ fao.org/fishery/topic/166283/en > (accessed 26 October 2013).

222 De Coning, E., supra nt. 25, 41.

223 Art. 43 WIF.

224 Artt. 25-28 WIF.

${ }^{225}$ Kahveci, E., Port based welfare services for seafarers, ITF Seafarers' Trust and Seafarers International Research Centre, Cardiff University, 2007, 8.

226 Surtees, R., supra nt. 21, 85. 
and human trafficking and the duress that trafficked seafarers/fishers may be under, which would inform what to ask and how and where to conduct interviews and screening. And port authorities (and even their ITF and union colleagues who are often present in ports and cooperate with authorities) may not always be well positioned or trained to interview crew and screen for signals of human trafficking. ${ }^{227}$ Lack of a common language may also serve as a barrier when interviews do take place. The "culture of the sea" may also influence what seafarers and fishers disclose to port authorities. One respondent in a study of FCVs in New Zealand's EEZ, when asked why abused crew did not complain to port State authorities, explained: 'What happens at sea stays at sea. No one talks about it. That's always been the culture...'228 That exploitation is, it seems, normative amongst seafarers and fishers (or at least not uncommon) can further reinforce the culture of silence and non-disclosure/noncomplaint.

Moreover, contacting authorities while in port is often complicated for seafarers and fishers, who may fear the authorities and not trust that they will be recognised as trafficked or, at minimum, in need of assistance. This was a deterrent for Ukrainian men trafficked to Turkey who feared the authorities and worried that they would replace one bad situation with another (i.e. being imprisoned in Turkey). ${ }^{229}$ Similarly, one Ukrainian seafarer who wanted to escape the Russian vessel on which he was trafficked did not want to be rescued, despite his horrendous ordeal, because he feared (complicit) authorities. ${ }^{230}$ Concerns about corruption have also been voiced in Southeast Asia-for example in a recent study in Thailand where, in spite of predeparture inspections being conducted on various boats and interviews being conducted with fishing crews by law enforcement, in cooperation with the National Fisheries Association of Thailand (NFAT), no cases of human trafficking were identified. ${ }^{231}$

Fishers and seafarers may also be concerned about their legal status in a country if they escape. Many have their passports and documents held by the captain or ship owner. ${ }^{232}$ Even those in possession of their documents may not have (or may have been told they do not have) the appropriate documents and visas, which would, if encountering authorities, lead to arrest and detention.

227 This should, to some extent be addressed as the MLC begins to be implemented. For more on this point see supra nt. 192. The EU Directive addresses this issue as well noting that: 'Officials likely to come into contact with victims or potential victims of trafficking in human beings should be adequately trained to identify and deal with such victims. That training obligation should be promoted for members of the following categories when they are likely to come into contact with victims: police officers, border guards, immigration officials, public prosecutors, lawyers, members of the judiciary and court officials, labour inspectors, social, child and health care personnel and consular staff, but could, depending on local circumstances, also involve other groups of public officials who are likely to encounter trafficking victims in their work.' Par. 25 of Directive 2011/36/EU of the European Parliament and of the Council of 5 April 2011 On Preventing and Combating Trafficking in Human Beings and Protecting its Victims, and Replacing Council Framework Decision 2002/629/JHA.

228 Stringer, C., et al., supra nt. 20, 14.

229 Surtees, R., supra nt. 21, 88.

230 Idem, 87.

231 Robertson, P., supra nt. 6, 15.

${ }^{232}$ Cf. Derks, A., "Migrant Labour and the Politics of Immobilisation: Cambodian Fishermen in Thailand", Asian Journal of Social Science, 38(6), 2010, 915-932; De Coning, E., supra nt. 25; ITF Report, supra nt. 17; Pearson, E., Punpuing, S., Jampaklay, A., Kittisuksathit, S., and Prohmmo, A., Mekong Challenge: Underpaid, Overworked and Overlooked: The Realities of Young Migrant Workers in Thailand, vol. 1, ILO/IPEC, 2006; Robertson, P., supra nt. 6; and Surtees, R., supra nt. 21. 
Fear of being blacklisted (and thus barred from future positions) also inhibits disclosure. Some recruitment agencies and vessel owners exploit this vulnerability by excluding (or threatening to exclude) seafarers and fishers from future employment opportunities through 'blacklisting'; blacklists are circulated among recruitment agencies. ${ }^{233}$ The practice not only hinders future employment opportunities, but is also used to intimidate seafarers and fishers from lodging complaints. One Indonesian man, trafficked aboard a fishing vessel in New Zealand, left the vessel while in port after several months of abuse and exploitation but was, as a consequence, blacklisted by the crewing agency, which prevented him finding placements through other crewing agencies. The agency also withheld his personal documents and professional accreditations (essential in finding future job placements) and his outstanding wages (about 1100USD). ${ }^{234}$ Although the practice of blacklisting is pervasive, by its nature it is difficult to regulate and document.

There needs to be a commitment on the part of port authorities to identify and then protect trafficked seafarers-removing them from their trafficking situation and offering appropriate services for recovery and return home. ${ }^{235}$ Commercial interests of port authorities can, at times, conflict with the goals of organisations assisting seafarers and fishers, as one ITF representative explained:

The port is not always so cooperative because it is commercial and to let the vessel stay for two to three days while the ITF inspector makes some claims to the court, it just takes time. ${ }^{236}$

Further, authorities may be concerned with the implications (i.e. liability) of detaining a vessel that is later assessed to be satisfactory as the costs of Port State Control inspections are borne by the port State authority. ${ }^{237}$

Opportunities for identification will necessarily differ from port to port. Just as there are FoCs, there are also 'ports of convenience', where the port is unable or unwilling to enforce its own State's maritime law. Such ports do not enforce fisheries management and conservation regulations and may be open to corruption in ways that facilitate lax enforcement of fishing quotas and licensing requirements. ${ }^{238}$ Lack of enforcement and opportunities for corruption represent serious obstacles in efforts to identify and assist trafficked seafarers and fishers. ${ }^{239}$ Fishing vessels that are unseaworthy or are engaged in illegal activities often make use of or move to ports with lax control and law enforcement regimes, which undermines other States' unilateral attempts to inspect and control fishing vessels. ${ }^{240}$

The above points notwithstanding, there have been rescues of trafficked fishers in ports - by, for example, joint operations of law enforcement and NGOs in Thailand. A recent trafficking study in the GMS involved a number of men and boys trafficked

${ }^{233}$ ITF Report, supra nt. 17, 26.

${ }^{234}$ Skinner, E., supra nt. 134. See also Stringer, C., et al., supra nt. 20.

${ }^{235}$ Surtees, R., supra nt. 21, 87.

${ }^{236}$ Idem, 88.

${ }^{237}$ Domestic legislation in both Australia and New Zealand absolves PSC of liability in such cases. It has become relatively common practice for States to levy a maritime safety charge upon vessels calling at their ports. And once a vessel is detained for non-compliance, provision is usually made for all costs to be borne by the ship owner. Hare, J., supra nt. 92.

${ }^{238}$ De Coning, E., supra nt. 17, 57 and 113.

239 Surtees, R., supra nt. 21, 85-87.

${ }^{240}$ De Coning, E., supra nt. 25, 25. 
for fishing (from Thailand, Cambodia and Myanmar) who were rescued through law enforcements raids in ports. ${ }^{241}$

\section{V.4. Lack of Identification of Trafficked Seafarers and Fishers Beyond Ports}

Some trafficked seafarers/fishers escape themselves-e.g. jumping off boats and swimming to shore or another vessel, escaping while in port, negotiating their release and so on. In such situations, they come into contact with various authorities who should be in a position to identify them as trafficked (or, at minimum, as vulnerable) and assist or refer them to appropriate authorities. However, it is not uncommon that they go unidentified due to, at least in part, a lack of knowledge of human trafficking in the fishing and seafaring sectors.

Many Cambodian and Burmese fishers have escaped from boats in Thailand, Malaysia and Indonesia and then ended up stranded without documents or a way to return home and also at risk of recapture or harm by the captain. One Cambodian man escaped the fishing vessel where he was exploited when it came into port in Indonesia. He and his colleagues fled the vessel and hid for some time but had little food and eventually approached the authorities for help. They explained their situation and asked for help but the law enforcement official did not recognise their case as trafficking and did not provide any help. Similarly, one Cambodian man trafficked to Malaysia for fishing escaped and went to the Malaysian authorities for help. He was not officially screened for trafficking but was instead detained as an irregular migrant and then deported. ${ }^{242}$

Overall, there is a need to increase collaboration between the anti-trafficking community and the seafaring and commercial fishing sectors, most pressingly in terms of identifying trafficked fishers and seafarers and offering them protection and assistance. Much of what is currently considered labour exploitation within the fishing and seafaring industry may, in fact, be human trafficking. And much of the antitrafficking community is unaware (or only becoming aware) of the presence of trafficking at sea. Inter-organisational dialogue, accompanied by collaboration on cases and awareness-raising efforts, will assist in better addressing this phenomenon. In addition, it is important to engage organisations for both fishers and seafarers. National organisations for seafarers on merchant ships do not always represent fishers; fishers usually have their own organisations. ${ }^{243}$

In some cases, embassies have been involved in identifying and repatriating trafficked fishers and seafarers. One Cambodian man trafficked to Malaysia on a fishing boat was initially arrested by the Malaysian police and charged with illegal migration but was later recognised as a trafficking victim by staff of his embassy when they visited the prison and interviewed Cambodian nationals there. The embassy worked with a Cambodian NGO to secure his release and arrange his return. Similarly, the Thai embassy was instrumental in the identification and return of Thai nationals trafficked for fishing who came into port in Yemen and contacted the

\footnotetext{
241 Surtees, R., supra nt. 6, 87-93.

242 Ibid. Other Cambodian men who were trafficked onto Thai vessels and escaped to Malaysia were then re-trafficked into forced labour on plantations. Without proper identification and assistance, the risks of re-trafficking, including into other sectors, is very high due to the vulnerability of fishers and seafarers who have escaped their initial trafficking situation on their own. UNIAP, supra nt. 33, 6.

243 Surtees, R., supra nt. 21, 130.
} 
embassy for assistance. ${ }^{244}$ That being said, this is only an option when there is a diplomatic presence in the country of identification, which was not the case, for example, for Cambodian men trafficked to South Africa as fishers who then faced great difficulty in findings help and getting home. ${ }^{245}$

At the same time, many fishers avoid contact with authorities because they are not aware of help that might be offered or trust that assistance would be forthcoming. For example, one Ukrainian fisher managed to negotiate his release from the Russian crabbing vessel on which he was trafficked, saying that his father was seriously ill. He was eventually released (but not paid) and made his way home by borrowing money from his Russian colleagues. When asked whether he considered seeking help in Russia he explained that he did not trust the Russian authorities and was also worried about exiting the country before his visa expired, fearing he would be arrested as an illegal migrant. He also did not feel able to approach the embassy, worried that they could not offer him any assistance. ${ }^{246}$ Similarly, one man from Myanmar trafficked on a Thai fishing boat managed to escape but avoided contact with Thai authorities because he feared being arrested and returned to his traffickers. He instead made his own way home and was identified as a trafficking victim only once he returned to Myanmar. ${ }^{247}$

Therefore, in addition to equipping authorities and stakeholders in destination countries with skills to identify trafficked seafarers and fishers, it is also important that seafarers and fishers are equipped with information about organisations and institutions from which they can solicit assistance in case of difficulty while in foreign ports/countries. Knowing whom to contact and how can be an important first step in identification, particularly in countries where authorities may not come into contact with trafficked seafarers and fishers unless they self-identify. This might include the ITF, seafarers and fishers associations and unions, organisations or institutions in destination countries and different anti-trafficking organisations. This might also include law enforcement authorities in transit or destination countries. Seafarers and fishers should be encouraged to travel with (and, if needed, hide) charged and credited mobile phones and establish a system of regular communication with family or friends on shore, the interruption of which can serve as a warning signal for possible difficulties. ${ }^{248}$

\section{V.5. Inadequate Provision of Assistance to Trafficked Seafarers and Fishers - Abroad and at Home}

As discussed above, the Trafficking Protocol encourages States Parties, in Article 6, to implement measures to provide for the assistance and protection of trafficking victims. ${ }^{249}$ Most countries have ratified the Trafficking Protocol and have, within their

244 Surtees, R., supra nt. 6, 45.

245 Sen, D. and Danson, C., 'Fishermen trafficker charged', Phnom Penh Post, May 13, 2013, available online at <phnompenhpost.com/2013051365574/National/fishermen-trafficker-charged.html> (accessed 20 November 2013).

246 Surtees, R., supra nt. 21, 97.

247 Surtees, R., supra nt. 6, 46.

248 Surtees, R., supra nt. 21, 97.

249 Measures, programmes, and services aimed at the recovery of trafficked persons may be offered by governmental, non-governmental or international organisations in countries of destination, transit and origin. These might include but are not limited to: accommodation/housing, medical care, psychological assistance, education, vocational training, life skills, employment and economic empowerment, legal assistance, transportation and family mediation/counselling. Assistance may 
national legislation, provisions for the assistance and support to trafficking victims who originate from, transit through or are trafficked to their country. Yet there appears to be inadequate provision of assistance and support to trafficked seafarers and fishers, both at home and abroad. Ukrainian seafarers and fishers trafficked to Russia and Turkey went unassisted in destination countries, often funding their own travel home. They received assistance only once they returned to Ukraine and even upon return there were barriers and issues in terms of how assistance was offered, which served to impede the provision of adequate support. ${ }^{250}$ Similarly, in a study of (re)integration in the Greater Mekong Sub-region, men and boys trafficked aboard fishing boats did not generally receive adequate support and assistance either in destination countries or in their own countries after return. ${ }^{251}$

Even when assistance was available, it was not always designed to meet the specific needs of trafficked seafarers and fishers. In Southeast Asia, the assistance framework for men is generally underdeveloped, which means trafficked fishers generally are unassisted or underassisted as a consequence. One man from Myanmar, trafficked for fishing, was detained by Thai officials and deported to Myanmar. After giving a statement to the Myanmar police and identified as a trafficking victim, he was given a bag of basic supplies. He returned home to his family and received no further support. Similarly, one Cambodian trafficked aboard a fishing boat explained how he was offered only very limited assistance from a list of pre-defined options with little assessment of his individual needs or situation: 'After identifying me [as a trafficking victim], they... asked me to choose between a motorcycle, water pump machine, a bicycle or 150USD'. ${ }^{252}$

The needs of trafficked seafarers and fishers, while not always dissimilar to victims of other forms of labour trafficking, may have some features which merit particular attention. The decision of whether to remain in the merchant fleet or commercial fishing sector (and how to work in this sector safely) is of immediate concern. To the extent that the needs of trafficked seafarers and fishers are distinct from those of other trafficking victims, governments and victim assistance groups should be prepared to meet those needs. Such support should be available in countries from which trafficked persons originated as well as where they were exploited or identified, including accommodating the legal issues associated with foreign nationals being assisted abroad (i.e. temporary residence permits including the right to work). ${ }^{253}$

Developing this specific assistance system may require building the skills and capacity of service providers to be able to work effectively with this group of trafficked persons. Experts from the seafaring and fishing sectors would be able to bring in a range of knowledge and resources that can help address many of the needs of trafficked seafarers and fishers. Anti-trafficking organisations, particularly service providers, have an equally important role to play in offering services (such as medical care, counselling and so on) to trafficked seafarers and fishers, particularly where government services are lacking.

Responsibility for offering assistance to trafficked fishers and seafarers rests not only with countries from which trafficked persons originate, but also with flag States

involve one or multiple services. Surtees, R. and Somach, S., Methods and models for mixing services for victims of domestic violence \& trafficking in persons in the Europe and Eurasia region, USAID, Creative Associates, Aguirre Division of JBS International and the NEXUS Institute, 2008, 48.

250 Surtees, R., supra nt. 21, 113-120.

251 Surtees, R., supra nt. 6, 53-56.

${ }^{252}$ Surtees, R., supra nt. 6, 99.

253 Surtees, R., supra nt. 21, 127. 
of the vessels on which they are exploited. In addition, coastal States and port States where trafficked persons may be identified also have responsibilities to offer assistance. The cost of this assistance should be borne not only by countries of origin and where victims are identified or escape, but also by flag States on whose ships trafficked persons are exploited. ${ }^{254}$ For example, the MLC sets forth that seafarers have a right to be repatriated at no cost to themselves in the circumstances and under the conditions specified in the Code. ${ }^{255}$ The MLC Code stipulates that if a ship owner fails to make arrangements for or to meet the cost of repatriation, the flag State is then responsible for arranging the repatriation of the seafarers concerned. If the flag State fails to do so then the State from which the seafarers are to be repatriated or the State of which they are nationals may arrange for their repatriation and recover the cost from the flag State. ${ }^{256}$ The MLC also seeks to ensure that seafarers have access to shore-based welfare facilities. ${ }^{257}$ States Parties are required, where welfare facilities exist, to ensure that they are available for the use of all seafarers. ${ }^{258}$ Further, States Parties are required to promote the development of welfare facilities in appropriate ports and to encourage the establishment of welfare boards to regularly review welfare facilities and services to ensure they are appropriate in light of the changing needs of seafarers. ${ }^{259}$ For fishers, the WIF Convention ensures their right to repatriation in Article 21. ${ }^{260}$

Offering a comprehensive assistance framework for this transnational crime will also require establishing links between organisations in origin and destination/flag State countries. Lack of communication channels between government agencies and victim assistance groups presents a major obstacle in return efforts as well as reintegration support and later civil lawsuits and prosecution. Organisations in origin countries should establish regular channels of communications and directories with organisations where trafficked seafarers and fishers are commonly identified or escape. They should share information about emergency contacts and avenues for assistance in order to improve transnational collaboration. Anti-trafficking organisations in the flag State should also be aware of their country's involvement in trafficking and should work with other countries to respond appropriately to the issue of human trafficking. International institutions, like Interpol, and international organisations, could play a role in communication and links between different countries. ${ }^{261}$

\section{Prosecution}

254 Ibid.

255 Regulation 2.5 MLC.

256 Standard A2.5 MLC. Standard A2.5 covers repatriation in depth, requiring States Parties to facilitate the repatriation of seafarers serving on ships which call at their ports or pass through their territorial or internal waters, as well as their replacement on board and further ensuring that States Parties do not refuse the right of repatriation to any seafarer because of the financial circumstances of a ship owner or because of the ship owner's inability or unwillingness to replace a seafarer.

257 Regulation 4.4 MLC.

258 Irrespective of nationality, race, colour, sex, religion, political opinion or social origin and irrespective of the flag State of the ship on which seafarers are employed or engaged or work. Standard A4.4 MLC.

259 Ibid.

260 Art. 21 WIF.

261 Surtees, R., supra nt. 21, 131. For example, in Bangkok in February 2012, a meeting was held on the formation of an INTERPOL ad hoc Fisheries Crime Working Group. The aim of the ad hoc FWG is to promote cost effective, predictive, efficient and timely fisheries law enforcement and crime detection. INTERPOL, supra nt. 95. 
Trafficked seafarers and fishers should have the opportunity to pursue legal recourse against their exploiters. The Trafficking Protocol requires, in Article 5, that States Parties adopt legislative and other measures to establish human trafficking as a criminal offense. ${ }^{262}$ States Parties, under Article 6, must ensure that measures are implemented to provide trafficking victims, when appropriate, with information on relevant legal and administrative proceedings and assistance to enable their views and concerns to be presented and considered at appropriate stages of criminal proceedings against offenders. Article 6 also requires States Parties to ensure that their domestic legal systems include measures that offer victims of trafficking the possibility of obtaining compensation for damage suffered. ${ }^{263}$ Similar provisions are contained in the other major relevant treaty: the Council of Europe Convention against Trafficking.

Effectively prosecuting trafficking at sea and offering compensation opportunities to trafficked seafarers and fishers is key to an anti-trafficking response. Prosecutions should serve to deter the exploitation of seafarers and fishers and contribute to a more robust and better enforced regulatory framework on the high seas as well as within territorial waters and EEZs. Providing compensation to trafficked seafarers and fishers, particularly when costs are borne by ship owners, should also serve as a deterrent in a profit driven industry. Compensation payments can also play an important role in the successful (re)integration of trafficked persons; returning home with money can support one's economic stability and success as well as ease relations (and mitigate stigma) within the family and community.

However, legal recourse in the case of trafficking at sea is complex. For trafficked seafarers and fishers there are various barriers and issues that serve to complicate their access to justice and the viability (and ultimate success) of criminal prosecutions and other forms of legal recourse. The raft of issues include: lack of legislation and legal expertise to address trafficking crimes at sea; difficulty discerning legal rights and the jurisdiction in which those rights can be enforced; the risk that trafficking victims will not be identified as victims and will be prosecuted for crimes committed while trafficked; inadequate prosecution of higher level traffickers; and lack of State accountability for trafficking at sea. The impunity of labour recruitment agencies is another impediment to successful prosecutions and civil litigation in trafficking at sea cases.

\section{VI.1.Lack of Adequate Legislation and Legal Expertise in all Relevant Fields of Law}

Access to legal recourse for trafficked seafarers and fishers requires an appropriate and relevant legislative framework. And yet in many situations the legislation needed to prosecute trafficking at sea is inadequate-either in terms of weak or lacking antitrafficking legislation or problems in legislation related to the fishing and seafaring sector.

The Trafficking Protocol requires States Parties to adopt legislative and other measures to establish human trafficking as a criminal offense. This should mean having in place effective anti-trafficking legislation that criminalises all forms of exploitation and includes effective, proportionate and dissuasive criminal penalties. And yet some human trafficking laws are limited to trafficking for sexual exploitation and/or the trafficking of women and children, inapplicable to trafficked seafarers and

262 Art. 5 Trafficking Protocol.
263 Art. 6 Trafficking Protocol. 
fishers who are typically adult male victims of labour trafficking. ${ }^{264}$ Moreover, in some countries there is no anti-trafficking legislation, making trafficked persons subject to greater uncertainties in terms of legal recourse (and their traffickers potentially facing reduced risks and penalties). ${ }^{265}$

Article 6 of the Trafficking Protocol requires States Parties to ensure that their domestic legal systems contain measures that offer victims the possibility of obtaining compensation for damages suffered. This provision does not obligate a State to provide compensation or restitution to victims, but under the Protocol, States Parties must ensure that mechanisms for providing compensation to trafficking victims exist. ${ }^{266}$ It is generally agreed that victims should be informed of their rights to compensation for: unpaid or underpaid wages; legal fees; excessive, fraudulent or illegal deductions from wages; reimbursement of illegal fees paid to a crewing agency; medical expenses; loss of opportunities; pain and suffering; and/or degrading and inhumane treatment. ${ }^{267}$ States should also be empowered to trace, freeze and seize assets in order to fund victim compensation payments or to establish a State-funded or subsidised compensation scheme to guarantee payments to trafficking victims. ${ }^{268}$

States also need to bring their national laws related to the fishing and seafaring sector into accord with the primary instruments of international maritime law that offer mechanisms to prevent and combat the trafficking of seafarers and fishers. Prosecuting a case of trafficking at sea requires national laws that guarantee seafarers and fishers the rights to a safe and secure workplace; fair terms of employment; and decent working and living conditions on board ship. Many States have not implemented the provisions of the IMO and ILO treaties that aim to ensure the rights

264 As of 2012, 19 of 162 countries and territories studied had 'partial' anti-trafficking legislation - that is, legislation that focused only on women or children or only one type of trafficking, such as sexual exploitation. See United Nations Office on Drugs and Crime, REPORT: Global Report on Trafficking in Persons, United Nations, 2012, 83.

265 That being said, the number of countries without anti-trafficking legislation is decreasing. By 2012, of 162 countries and territories examined there were 134 that had enacted legislation criminalising all or most forms of trafficking and only nine that did not have an offence on trafficking in persons in domestic law (compared to thirty five in 2008). This is a positive trend. Idem, 82-83.

${ }^{266}$ Pursuant to Article 15 of the CoE Convention, States Parties are required to take steps to guarantee the compensation of victims.

267 United Nations Office on Drugs and Crime, Anti-human trafficking manual for criminal justice practitioners, United Nations, 2009, Module 13, available online at <unodc.org/documents/humantrafficking/TIP_module13_Ebook.pdf $>$ (accessed 15 November 2013). Indeed, under the Trafficking Protocol, States Parties must ensure that their domestic legal systems contain measures that offer victims of trafficking in persons the possibility of obtaining compensation for damage suffered. Art. 6 Trafficking Protocol.

268 See, e.g., Gallagher, A. and Karlebach, N., Prosecution of Trafficking in Persons Cases: Integrating a Human Rights-Based Approach in the Administration of Criminal Justice, OHCHR, 2011, available online at <works.bepress.com/cgi/viewcontent.cgi?article=1019\&context=anne_gallagher> (accessed 2 November 2013). According to the UNODC Legislative Guide for the Implementation of the Trafficking Protocol, generally States have developed one or more of the following three possibilities for obtaining compensation or restitution: (a) Provisions allowing victims to sue offenders or others under statutory or common law torts for civil damages; (b) Provisions allowing criminal courts to award criminal damages, or to impose orders for compensation or restitution against persons convicted of offences; and (c) Provisions establishing dedicated funds or schemes whereby victims can claim compensation from the State for injuries or damages suffered as the result of a criminal offence. United Nations Office on Drugs and Crime, Legislative Guides for the Implementation of the United Nations Convention Against Transnational Organized Crime and the Protocols Thereto, 2004, par. 369, available online at <unodc.org/pdf/crime/legislative_guides/Legislative\%20guides_Full\%20version.pdf> (accessed 2 November 2013). 
of seafarers and fishers, leaving seafarers and fishers unprotected and vulnerable to trafficking. States should ratify the applicable IMO and ILO conventions, particularly the MLC and WIF Convention. The IMO and the ILO should continue to update and amend treaties already in force to address the changing needs of seafarers and fishers. For example, the 2010 amendments to the STCW (which increased the weekly rest hours required for seafarers and require the recording of rest hours) offer an opportunity for vigorous enforcement by PSC officers and legal recourse for seafarers. ${ }^{269}$ Legislators should ensure that national laws are in accordance with the obligations of States Parties under the IMO and ILO conventions to guarantee seafarers and fishers the minimum rights to a safe and secure workplace; fair terms of employment; and decent working and living conditions on vessels.

Also critical is the implementation of relevant existing legislation and regulations. Prosecutors and investigators should actively pursue cases of trafficking at sea in order to create robust case law and to streamline future prosecutorial efforts. Prosecutors should ensure that crewing agencies are investigated and attached to lawsuits involving trafficking on vessels on which trafficked persons have been exploited. Identifying competent legal experts might be possible by partnering with law firms that currently work on behalf of seafarers and fishers facing labour difficulties. These firms, while not generally well-versed in trafficking legislation, often advocate and pursue legal recourse for seafarers and fishers who face problems not dissimilar to trafficking. The ITF also has experience in helping seafarers secure outstanding wages and could serve as a resource in pursuing compensation for trafficked seafarers. ${ }^{270}$ Targeted trainings for prosecutors, police and judges on the handling of trafficking cases in the maritime context will be crucial in effectively pursuing these cases. ${ }^{271}$

Beyond legislation is the need for legal expertise in the relevant fields of law. Representing trafficked seafarers and fishers may involve international maritime law, the law of the sea, and various national laws (including labour laws, anti-trafficking legislation and so on), all of which require highly specialised attorneys to effectively litigate. Access to such expertise may be limited and serve to constrain and undermine prosecutorial efforts. For example, Ukrainian seafarers felt that they had inadequate access to competent legal representation, as one seafarer explained:

They told us that he [the lawyer] would take care of our legal case.... But we realised that this lawyer would not be competent enough, since he did not know the seafaring field in any detail. [Arguing a case like this] requires specific knowledge of the seafaring industry. ${ }^{272}$

There is a need to build a comprehensive legislative framework for the prosecution of trafficking at sea. Legislators should ensure accountability laws contain no loopholes (such as operations in international waters or by flying a flag under a non-

269 Amendments to the STCW Convention and Code of 25 June 2010, available online at $<$ www.imo.org/OurWork/HumanElement/TrainingCertification/Pages/STCW-

Convention.aspx > (accessed 19 November 2013).

270 For example, in May 2013 a group of Ukrainian and Russian seafarers, assisted by the ITF, brought proceedings against the owner of a Belize-flagged freighter (the freighter had been left stranded in Dublin and the crew had not been paid since December 2012) to retrieve their unpaid wages. The Dublin High Court allowed the ship to be sold to cover the wage debts. The bank then guaranteed to pay the crew wage arrears of $€ 247,361$ (US\$321,000), plus their repatriation, while it resolved its dispute with the ship's owners. See ITF Seafarers, Maritime News, 21 May 2013, available online at $<$ itfseafarers.org/maritime_news.cfm> (accessed 15 November 2013).

271 Surtees, R., supra nt. 21, 129.

272 Idem, 106. 
cooperative jurisdiction) and that both criminal and civil reactions are commensurate with the gravity of the crime.

Legislators should also ensure that laws establish liability for negligent or wilfully ignorant placement of crew members that leads to trafficking. Legal accountability should also be pursued in terms of the registered owner of the vessel, the operator and the trader of illegal catch, where relevant. This would ideally serve as a deterrent for persons and companies that currently benefit from such activities. ${ }^{273}$

Finally, collaboration is needed between relevant legal specialists and fields of law. Legal professionals will need the knowledge and experience of specialists to effectively represent trafficked seafarers and fishers. Organisational rosters of relevant attorneys, online collaboration or consultation forums and inter-specialty academic study can contribute to increasing the links between these legal fields. Creating a central repository of case law in the seafaring and commercial fishing sector can be a useful tool in further pursuing cases involving trafficking at sea. This should include relevant treaties, international agreements, customary law, case law, national legislation, academic articles and any other resources that may be useful to an attorney attempting to pursue civil or criminal action on behalf of a victim of trafficking at sea. Jurisdictional issues will likely be one of the main obstacles faced in such cases, which makes it essential for governments to communicate, cooperate and learn from each other. ${ }^{274}$

\section{VI.2.Barriers Between Different Jurisdictions and Legal Systems}

The investigation and prosecution of trafficking cases is often stymied by barriers between different jurisdictions and legal systems. Barriers include the cross border nature of the crime, the different jurisdictions involved, the different legal frameworks, the involvement of different law enforcement agencies, transfer of evidence, issues of language/translations and so on. Tackling these complex and interrelated challenges requires cooperation between law enforcement agencies and judicial systems across borders beyond the formal means of mutual legal assistance treaties.

One major impediment in many transnational trafficking prosecutions is difficulties in accessing and the availability of victim/witnesses. While many trafficked Ukrainian seafarers were willing to serve as witnesses in criminal or civil proceedings, they were unable to do so because of long distances between their homes and the sites of their lawsuits and the associated (and prohibitive) costs of travelling to serve as victim/witnesses. Other obstacles included leaving family members behind, staying away for an unknown period of time, losing income while not working and potentially missing out on new employment opportunities during their absence. ${ }^{275}$

The importance of international cooperation to the investigation and prosecution of trafficking crimes is widely recognised. ${ }^{276}$ Bilateral or multilateral agreements that

\footnotetext{
Idem, 129.

Ibid.

275 Idem, 107.
}

276 One of the three basic purposes of the Trafficking Protocol is to promote international cooperation to prevent, suppress and punish trafficking in persons and the primary aim of the United Nations Convention Against Transnational Organized Crime (UNTOC) is international cooperation to prevent and combat transnational organised crime. See UNODC, ASEAN Handbook on International Legal Cooperation in Trafficking in Persons Cases, UNODC and Australian Government Aid Program, 2010, available online at <unodc.org/documents/humantrafficking/ASEAN_Handbook_on_International_Legal_Cooperation_in_TIP_Cases.pdf $>$

(accessed 15 November 2013). 
serve to overcome barriers between different jurisdictions and legal system might cover such matters as evidence sharing, testimonial admission, database collaboration and the like, and are crucial to the successful investigation and prosecution of trafficking cases. It is also worth exploring links to related crossover crimes, such fisheries crimes, and how cooperation between these sectors/issues can strengthen investigations and prosecutions. Mutual legal assistance-the process by which States request other States to provide information and evidence for the purpose of an investigation or prosecution - is a cooperation mechanism that could be used to take evidence or statements from persons in a foreign jurisdiction that would be admissible in a criminal trial. ${ }^{277}$ Both informal cooperation (such as the exchange of information between law enforcement in different States) and formal cooperation (such as mutual legal assistance or treaty-based cooperation) are necessary in overcoming existing barriers between different legal jurisdictions and systems in prosecuting trafficking at sea.

Such obstacles apply in almost any form of trafficking litigation but are perhaps more pressing in the case of trafficking at sea with so many jurisdictions and legal frameworks involved. Experimentation in addressing this problem will contribute to non-seafaring cases as well. Conversely, efforts made in other areas of trafficking to overcome these barriers may be learned from, or carried over, to the seafaring and fishing sectors.

\section{VI.3.Prosecution and Penalisation of Trafficking Victims for Crimes Committed While Trafficked}

Trafficked persons may be required to or unknowingly commit criminal offences or other violations of the law directly connected with, or arising out of, their trafficking situation. ${ }^{278}$ Trafficked fishers may be involved in IUU fishing or various forms of marine resource crime. Trafficked seafarers may be at risk of criminalisation for a range of crimes-e.g. breaching port rules; violating customs rules; ferrying illegal cargo; criminal negligence in discharging their duty as seafarer; using false certificates; carrying undeclared goods; and false logbook entry-even if their rank means the crimes committed are outside of their area of knowledge or competence. ${ }^{279}$ Both trafficked fishers and seafarers are also at risk of being charged with immigration offences. ${ }^{280}$ Fear of being charged with criminal activities undertaken while trafficked can serve as a deterrent in approaching authorities or answering questions truthfully when interviewed by authorities who may be able to identify and assist them.

The criminalisation of trafficked fishers and seafarers goes against protection obligations and may cause authorities to miss the opportunity to prosecute traffickers.

277 Taking evidence or statements from persons is a common type of mutual legal assistance.

${ }^{278}$ See Organization for Security and Co-operation in Europe (OSCE), Policy and legislative recommendations towards the effective implementation of the non-punishment provision with regard to victims of trafficking in consultation with the Alliance against Trafficking in Persons Expert Co-ordination Team, SEC.GAL/73/13, 22 April 2013.

${ }^{279}$ For a list of criminal charges faced by seafarers, see Seafarers' Rights International, Seafarers and the Criminal Law, available online at <seafarersrights.org/seafarers_subjects/seafarers_criminal_law > (accessed 2 November 2013).

$280 \mathrm{CoE}$ Convention and EU Directive. The criminalisation of seafarers (and not just trafficked seafarers) is an issue that is garnering increasing attention in the merchant sector. Seafarers' Rights International, supra nt. 279. The awareness and concern in recent years over environmental pollution has also had the 'unfortunate side effect' within the maritime industry of the tendency to criminalise seafarers for 'offenses committed unintentionally and/or unavoidably during the course of their professional duties.' ITF Report, supra nt. 16, 29. 
The principle of non-prosecution has been given some limited legal expression, most particularly within Europe. ${ }^{281}$ The CoE Convention, for example, emphasises the importance of ensuring that victims of human trafficking are not prosecuted or otherwise held responsible for offences, be it criminal or other, committed by them as part of the crime of trafficking. Article 26 states:

Each Party shall, in accordance with the basic principles of its legal system, provide for the possibility of not imposing penalties on victims for their involvement in unlawful activities, to the extent that they have been compelled to do so. ${ }^{282}$

Legislators should implement provisions to ensure that trafficked seafarers and fishers are not held criminally or administratively liable (such as subject to fines) for offences committed as a result of being trafficked. In spite of any existing legislation that protects trafficking victims from criminalisation, indirect violations of the principle of non-criminalisation still may occur-e.g. from the failure of authorities to identify a person as a trafficking victim. In other cases, authorities dealing with an offence committed by a trafficked seafarer or fisher may be aware that the individual is, in fact, a victim of trafficking but still fail to attach appropriate significance to that fact when determining responsibility for the crime. ${ }^{283}$ States must, therefore, also take action to ensure that trafficked seafarers/fishers are identified, which necessitates training the appropriate authorities in identification and the (sensitive and appropriate) handling of trafficking cases. In all cases where criminal charges are brought against fishers and seafarers, they should be offered interpretation and translation services if needed, legal representation and clear information about their legal rights.

\section{VI.4.Lack of Prosecution of Higher Level 'Traffickers' - i.e. Ship owners, Ship Operators}

In trafficking at sea there are many parties who may somehow play a role in trafficking - e.g. the broker or crewing agency, captains, non-trafficked crew on board a ship, ship owners, the flag State and so on. But the person with knowledge (or even who should have knowledge) that trafficking is occurring on a vessel and who may be

281 OSCE, supra nt. 278, citing Art. 26 CoE Convention and EU Directive. The UNOHCHR's Recommended Principles and Guidelines on Human Rights and Human Trafficking also offer considerations on non-punishment of trafficked persons, namely Principle 7, concerning protection and assistance, which states 'Trafficked persons shall not be detained, charged or prosecuted for the illegality of their entry into or residence in countries of transit and destination, or for their involvement in unlawful activities to the extent that such involvement is a direct consequence of their situation as trafficked persons.' OHCHR, Recommended Principles and Guidelines on Human Rights and Human Trafficking of the Office of the United Nations High Commissioner for Human Rights (E/2002/68/Add.1), available online at <ohchr.org/Documents/Publications/Traffickingen.pdf> (accessed 2 November 2013).

282 Art. 26 CoE Convention. The 2011 EU Directive emphasizes this point: 'Victims of trafficking in human beings should, in accordance with the basic principles of the legal systems of the relevant Member States, be protected from prosecution or punishment for criminal activities such as the use of false documents, or offences under legislation on prostitution or immigration, that they have been compelled to commit as a direct consequence of being subject to trafficking. The aim of such protection is to safeguard the human rights of victims, to avoid further victimisation and to encourage them to act as witnesses in criminal proceedings against the perpetrators.' Para. 14 EU Directive.

283 OSCE, supra nt. 278, 12. 
subject to criminal prosecution will vary by case. ${ }^{284}$ Many questions arise as to who is a 'trafficker', which is important not only in a criminal prosecution, but also in claims for compensation or restitution.

Take, for example, the recent successful prosecution of the Samaesan Case in Thailand, in which nine men from Myanmar were sold to a broker who exploited them on fishing trawlers. After two victims were able to secure their release, they contacted the Thai authorities and the Thai Department of Special Investigation rescued the remaining victims. The broker was arrested, charged and found guilty of seven charges including human trafficking. ${ }^{285} \mathrm{He}$ was sentenced to 33 years imprisonment. While this is an example of successful prosecution, questions remain about the other individuals involved in their exploitation. ${ }^{286}$

Targeting brokers or senior crew for their role in trafficking at sea may give some relief in individual cases. However, while exploitation of fishers may be meted out by senior crew, others may be complicit in the trafficking situation. ${ }^{287}$ Thus, pursuing the larger organisational structure will arguably have a more lasting effect. ${ }^{288}$ For example, fishing operators are likely to gain profit from the criminal activity and may be in a better position than senior crew to influence and put an end to abusive practices. Fishing operators' participation in forced labour and human trafficking offences must be identified and investigated. ${ }^{289}$ There are some tools that can be drawn upon, not least the WIF Convention, which provides that the fishing vessel owner (fishing operator) has the overall responsibility to ensure that the skipper has the necessary resources and facilities to comply with the provisions of the Convention. ${ }^{290}$ Issues such as salaries, food and medical supplies and maintenance and construction of vessels are likely to be influenced by the fishing operator.

That being said, it may prove difficult to target ship owners or individuals higher up the organisational ladder. Shipping practice is such that there is often a web of corporate identities involving the ship and various actors placed between the seafarer and the ship owner (such as manning agencies or ship management firms). ${ }^{291}$ For fishers, targeting criminal fishing operators (and the profit they make) is also challenging as they will often avail themselves of the protection of non-transparent corporate structures in jurisdictions that hide the identity of the ownership interests in

284 A recent report from the ILO notes that while in cases of forced labour the employer is the perpetrator, in cases of trafficking at sea the perpetrators may additionally include 'brokers, recruitment agencies, corrupt border or port officials, migrant smugglers, senior crew on board vessels and the fishing operator deriving profit from the exploitation.' De Coning, E., supra nt. 25, 21.

285 The seven charges were: deprivation of liberty of others; deprivation of liberty of a child; dishonestly receiving, disposing of, procuring, seducing or taking away of a minor; trafficking in persons for labour exploitation; trafficking in persons committed by an organised criminal group; smuggling of migrants; and assisting illegal immigrants to illegally stay in Thailand. Centre Against International Human Trafficking, Office of the Attorney General, Samaesan Case, Criminal Court in Bangkok, 28 January 2013, UNODC Human Trafficking Case Law Database Case No. THA011, available online at

doc/traffickingpersonscrimetype/tha/2013/samaesan.html?tmpl=old $>$ 2013).

286 Ibid.

287 De Coning, E., supra nt. 17, 40.

288 Ibid.

289 Ibid.

290 Art. 8 WIF Convention.

291 ITF Seafarers, How to find your way around the legal maze, 2006. $<$ unodc.org/cld/case-law(accessed 2 November 
the fishing company. ${ }^{292}$ In spite of the challenges, legal accountability should be pursued in terms of the registered owner of the vessel, the operator and the trader of illegal catch, where relevant. This would ideally serve as a deterrent for persons and companies that currently benefit from this activity. ${ }^{293}$

One option to reach members of the larger organisational structure is to engage actors such as the International Transport Workers' Federation (ITF). ${ }^{294}$ The ITF does not have arresting power, but it does have inspectors who can liaise with PSC and put pressure on ship owners to resolve problems on board. ${ }^{295}$ Further, the ITF can exert political pressure and use its networks to determine the owners of a vessel and support crew in bringing lawsuits against them. For example, in 2007, the ITF assisted the fishing crew of a vessel that had been detained by the Maritime Coastguard Agency (MCA) of Scotland for three weeks for technical reasons. After the detention the vessel owners changed the vessel's name and transferred registration from the British flag to St. Kitts and Nevis, at which point the MCA were no longer able to detain the vessel or assist the crew in their claims for wages and human rights abuses. The ITF enlisted the support of two Scottish unions and had the vessel arrested on behalf of the crew. Shortly thereafter the vessel owners lodged $\$ 75,000$ into the ITF Solicitors account so that the arrest could be lifted and the crew could be paid what they were due and then repatriated. ${ }^{296}$

States should also consider implementing and enforcing victim compensation schemes that target ship owners and operators. Administrative sanctions are another mechanism that could be used to pursue the larger organisational structure. For example, because under Italian law companies can face sanctions when their employees commit crimes, the owner and operator of the Costa Concordia was fined 1.3 million USD in a plea bargain for the blunders, delays and safety breaches that contributed to the 2012 shipwreck off the coast of the Italian island of Giglio. ${ }^{297}$ Such sanctions might be levied against owners of vessels onto which seafarers and fishers are trafficked. Fines against ship owners for pollution are already in place; this might be a model for another tool in targeting the larger organisational structure when prosecuting trafficking at sea.

\section{VI.5.Lack of State Accountability for Trafficking at Sea}

${ }^{292}$ The profit gained from their criminal activities will often be laundered through their seemingly legitimate business operations. More research is called for into the role of fishing operators in human trafficking for the purpose of forced labour at sea, how they are structured and how they launder the proceeds of their criminal activity. De Coning, E., supra nt. 17, 40.

${ }^{293}$ Surtees, R., supra nt. 21, 129.

${ }^{294}$ The ITF is an international trade union federation of around 700 transport workers' unions representing over 4.5 million transport workers from some 150 countries. It is one of several Global Federation Unions allied with the International Trade Union Confederation (ITUC).

${ }^{295}$ ITF inspectors inspect ships calling in their ports to ensure that seafarers have decent pay, working conditions and living conditions on board. If necessary they are able to assist with actions to protect seafarers' rights as permitted by law. All ITF Inspectors speak English as well as their own native language and--in some cases--other languages. See ITF Seafarers, About the Inspectorate, available online at $\leq$ itfseafarers.org/inspectorate.cfm $>$ (accessed 2 November 2013). See also ITF, What an ITF Inspector can/can't do, available online at $<$ www.itfseafarers.org/what-inspector-can-cantdo.cfm> (accessed 2 November 2013).

${ }^{296}$ ITF, supra nt. 136.

${ }^{297}$ Criminal charges against the captain of the Costa Concordia are still pending, as are several private civil lawsuits against the owner and operator. 
The prosecution of trafficking crimes that take place at sea will most often depend on the State exercising control over a vessel. Therefore flag State responsibility is a critical issue in ensuring that trafficked seafarers and fishers have access to legal recourse. The IMO, like the ILO, relies on pressures between States for the enforcement of treaties. If States allow for unaccountability, trafficking at sea can continue with impunity.

The presence of FoCs demonstrate a lack of State accountability; through FoCs it is possible to avoid labour regulation in the country of ownership, pay lower wages, force long hours of work and allow unsafe working conditions. ${ }^{298}$ However, it is not only FoC States ${ }^{299}$ that are unwilling or unable to contribute to a more transparent and responsible system. There are also the accompanying issues of FoC States and States that allow their national ship owners and operators to register vessels under FoCs to benefit from a system through which they avoid responsibility.

There are some mechanisms to put pressure on States to ensure flag State responsibility. For example, ITF's FoC campaign aims to eliminate the FoC system by achieving global acceptance of a genuine link between the flag a ship flies and the nationality or residence of its owners, managers and seafarers. ${ }^{300}$ The ITF also has collective agreements with vessels, which set the wages and working conditions for crews on FoC vessels irrespective of nationality, thereby affording protection to nearly 150,000 seafarers and inspecting vessels to ensure compliance. ${ }^{301}$ Soft law (such as declarations, statements, action plans and other forms of standard-setting) used by non-State actors, such as multinational corporations, trade unions, pressure groups and other NGOs, should be developed to put pressure on States to ensure flag State responsibility. ${ }^{302}$

For example, the Voluntary IMO Member State Audit Scheme is a tool to achieve harmonised and consistent international implementation of IMO standards. Under the Scheme, IMO Member States volunteer to be audited and receive a comprehensive and objective assessment of how effectively they administer and implement the mandatory IMO instruments covered by the Scheme. In addition, the lessons learned from audits can be provided to all IMO Member States to spread benefits shared. ${ }^{303}$

298 See ITF Seafarers, FoCs, available online at <itfseafarers.org/focs.cfm $>$ (accessed 2 November 2013). The FoC Campaign also encompasses an industrial campaign designed to ensure that seafarers who serve on flag of convenience ships, whatever their nationality, are protected from exploitation by ship owners.

299 As of August 2013 the ITF's Fair Practices Committee has declared the following 34 countries FoCs: Antigua and Barbuda; Bahamas; Barbados; Belize; Bermuda (UK); Bolivia; Burma; Cambodia; Cayman Islands; Comoros; Cyprus; Equatorial Guinea; Faroe Islands (FAS); French International Ship Register (FIS); German International Ship Register (GIS); Georgia; Gibraltar (UK); Honduras; Jamaica; Lebanon; Liberia; Malta; Marshall Islands (USA); Mauritius; Moldova; Mongolia; Netherlands Antilles; North Korea; Panama; Sao Tome and Príncipe; St Vincent; Sri Lanka; Tonga; and Vanuatu. See ITF, Current Registries Listed as FoCs, available online at $\leq$ itfseafarers.org/foc-registries.cfm> (accessed 2 November 2013).

300 ITF Seafarers, About the FoC Campaign, available online at $\leq$ itfseafarers.org/FOC_campaign.cfm> (accessed 2 November 2013).

301 Ibid.

${ }^{302}$ For a discussion of the function of soft law in the international community and the consequences the proliferation of soft instruments imply for international labour law in particular, see Duplessis, I., Soft law and International Labour Law, Labour law: Its role, trends and potential, ILO Labour Education 2006/2-3 No. 143-144, 2006, available online at <ilo.org/wcmsp5/groups/public/--ed_dialogue/---actrav/documents/publication/wcms_111442.pdf> (accessed 2 November 2013), 37-46.

303 See IMO, Voluntary IMO Member State Audit Scheme, available online at <imo.org/ourwork/safety/implementation/pages/auditscheme.aspx\#> (accessed 2 November 2013) and Barchue, L.D., Making a case for the Voluntary IMO Member State Audit Scheme, Paper 
States can also put pressure on each other to comply with their flag State obligations under the law of the sea and maritime law. States can lodge complaints with the IMO Council regarding compliance with the mandatory IMO instruments.

Listings may potentially be a tool in fostering flag State responsibility. The International Chamber of Shipping (ICS), for example, publishes an annual Shipping Industry Flag State Performance Table. Unlike other listings, flag States on the ICS performance table are not ranked but are judged against various performance criteria. The ICS performance table is intended to encourage ship owners to maintain a dialogue with their flag administrations to effect any improvements that might be necessary in the interests of safety, the environment and decent working conditions. ${ }^{, 304}$ Ship owners will weigh the performance of a flag State in deciding whether or not to join a registry, putting some pressure on a flag State to do well when being evaluated.

States can also use international relations to emphasise the importance of flag State responsibility. For example, after the United Nations and the United States enacted sanctions against Iran in 2012, several countries were quick to deregister Iranian vessels from their flags. Any State that registered Iran's ships would risk being exposed to the sanctions, particularly a ban from accessing the U.S. financial system. ${ }^{305}$ This demonstrates the power that international relations play in the system of FoCs and the potential State pressure can have to ensure flag State responsibility. The United States already uses unilateral sanctions in the fight against trafficking through the issuance of the annual State Department TIP Report and accompanying rankings. ${ }^{306}$ The TIP report has exercised a strong influence on the way in which States have responded to human trafficking. ${ }^{307}$ The TIP Report could, in addition, include flag State responsibility and performance in ranking countries in their fight against trafficking. If the TIP Report were to highlight trafficking issues in the maritime and commercial fishing sectors and emphasise the need for States to prosecute trafficking crimes that occur on vessels flying their flags and provide legal recourse for trafficked seafarers and fishers, this would go some way in the fight against trafficking at sea.

Finally, part of State accountability is the emerging policy in fisheries management and conservation of 'control over nationals', which could involve pursuing criminal

delivered at a seminar on "Auditing Flag States: New Directions for Smaller Maritime States," Malmø, World Maritime University, October 2005, available online at <imo.org/OurWork/Safety/Implementation/ Documents/Voluntary.pdf> (accessed 2 November 2013).

304 Marine Log, ICS Issues Flag State Performance Table, 14 January 2013, available online at $<$ www.marinelog.com/index.php?option=com_k2\&view=item\&id=3452:ics-issues-flag-stateperformance-table\&Itemid $=230>$ (accessed 19 November 2013).

305 See, e.g., Faucon, B., "Iran Shippers Face Difficulty Dodging Sanctions", Wall Street Journal, 28 September 2012.

306 In addition to outlining major trends and ongoing challenges in combating TIP globally, the United States TIP report provides a country-by-country analysis and ranking based on what progress foreign countries have made in their efforts to prosecute traffickers, protect victims, and prevent TIP. States that do not cooperate in the fight against trafficking and that therefore receive a Tier 3 ranking may be subject to U.S. foreign assistance sanctions. On 13 September 2010, President Barack Obama determined that two Tier 3 countries would be sanctioned for FY2011 without exemption (Eritrea and North Korea) and that four Tier 3 countries would be partially sanctioned (Burma, Cuba, Iran, and Zimbabwe). Siskin, A. and Sun Wyler, L., Trafficking in Persons: U.S. Policy and Issues for Congress, Congressional Research Service, 23 December 2010.

307 Gallagher, A. "Improving the Effectiveness of the International Law of Human Trafficking: A Vision for the Future of the US Trafficking in Persons Reports", Human Rights Review, vol. 12, ed. 3, 2011, 381-400. 
charges against the owners and operators of vessels. ${ }^{308}$ States have jurisdiction over their nationals for crimes they commit or are complicit in wherever they occur. Therefore, the exercise of criminal jurisdiction over nationals could be a supplementary measure in combating forced labour and human trafficking in the merchant and fishing sectors, in lieu of effective exercise of flag State prescriptive and enforcement jurisdiction. Yet, to effectively exercise control over nationals, States need to criminalise their nationals' participation in forced labour and human trafficking abroad and have access to information about their nationals' involvement in these activities to facilitate investigation and prosecution of suspected offenders. In practice, it is difficult for States to ascertain the involvement of their nationals in criminal activities taking place on board fishing vessels and within the merchant fleet. ${ }^{309}$

\section{Conclusion}

Trafficking at sea, while arguably less considered than other forms of labour trafficking, is nonetheless an important part of the overall picture of human trafficking. It is also a highly specific form of trafficking, which is subject to a distinct legal and regulatory framework and necessitates a very specific and targeted response in the fields of prevention, protection and prosecution. Seafaring and commercial fishing have a unique potential to be exploitative and dangerous labour sectors. The very nature of the work--largely out of sight; at sea and, thus, inescapable; and moving between various national and international jurisdictions--lends itself to a high risk of abuse and exploitation. Trafficking at sea is made significantly more feasible by the limited regulation of labour practices in the seafaring and fishing sectors. This is particularly acute in terms of commercial fishing for which the legal and regulatory framework is weaker than for merchant vessels.

The current legal and regulatory framework in which seafaring and fishing operates is generally weak, affording both space and opportunity for dangerous and exploitative practices including human trafficking. This paper has considered the existing mechanisms and gaps within the legal and regulatory framework of the seafaring and fishing sectors, as well as the key differences between the two. It has equally highlighted what legal and regulatory tools exist--under anti-trafficking law, international maritime law and the law of the sea--to combat trafficking at sea.

The paper also presents where changes and improvements can be made to more effectively prevent, protect and prosecute trafficking in the seafaring and commercial fishing sectors, thus outlining possible ways forward for governments, international organisations, non-governmental organisations (NGOs), unions and associations. Key issues that merit attention and could go some way in addressing human trafficking include the following, framed around the 3Ps.

${ }^{308}$ For example, the IPOA-IUU states: 'In the light of relevant provisions of the 1982 UN Convention, and without prejudice to the primary responsibility of the flag State on the high seas, each State should, to the greatest extent possible, take measures or cooperate to ensure that nationals subject to their jurisdiction do not support or engage in IUU fishing. All States should cooperate to identify those nationals who are the operators or beneficial owners of vessels involved in IUU fishing.' Art. 18 IPOA-IUU. The EU Directive also addresses this issue, stating that Member States shall take the necessary measures to establish their jurisdiction over trafficking offences where (a) the offence is committed in whole or in part within their territory; or (b) the offender is one of their nationals. Art. 10 EU Directive.

309 De Coning, E., supra nt. 25, 49. 


\section{Prevention:}

- Prohibit the payment of recruitment fees borne by seafarers/fishers to decrease trafficking vulnerability.

- Enforce accountability of crewing agencies in terms of job placements for fishers and seafarers.

- Improve regulation to prevent the used of fraud and deception in the recruitment of seafarers and fishers.

\section{Protection:}

- Improve identification of trafficked seafarers and fishers on the high seas, not least through enhanced flag State responsibility.

- Enhance identification of trafficked seafarers and fishers in territorial waters and EEZs through coastal State engagement and cooperation with flag States.

- Increase identification of trafficked fishers and seafarers, drawing on coastal State jurisdiction, PSC and resources within a port.

- Improve and expand identification efforts of trafficked seafarers and fishers beyond ports, with costs to be borne by flag States as well as countries of origin and destination.

- Ensure adequate provision of assistance to trafficked seafarers and fishers abroad and at home.

\section{Prosecution:}

- Improve legislation and legal expertise in all relevant fields of law to effectively prosecute trafficking at sea.

- Cooperate and coordinate transnationally to overcome barriers between different jurisdictions and legal systems.

- Prohibit the prosecution and penalisation of trafficking victims for crimes committed while trafficked.

- Pursue prosecution of higher level 'traffickers' - i.e. ship owners, ship operators and so on.

- Advocate and act to enforce State accountability for trafficking at sea.

Addressing trafficking within the seafaring and fishing sectors needs to be part of the development of a broader strategy by all stakeholders of how to provide greater protection and rights within the seafaring and commercial fishing sectors, which, in the long term, will serve to both prevent and combat human trafficking at sea. 